\title{
Pathways to Carbon Pollution: The Interactive Effects of Global, Political, and Organizational Factors on Power Plants' $\mathrm{CO}_{2}$ Emissions
}

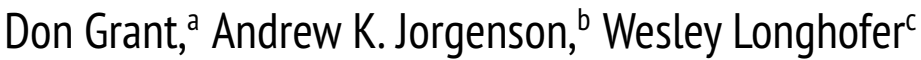

a) University of Colorado Boulder; b) Boston College; c) Emory University

Abstract: Climate change is arguably the greatest threat to society as power plants, the single largest human source of heat-trapping pollution, continue to emit massive amounts of carbon into the atmosphere. Sociologists have identified several possible structural determinants of electricity-based $\mathrm{CO}_{2}$ emissions, including international trade and global normative regimes, national political-legal systems, and organizational size and age. But because they treat these factors as competing predictors, scholars have yet to examine how they might work together to explain why some power plants emit vastly more pollutants than others. Using a worldwide data set of utility facilities and fuzzy-set methods, we analyze the conjoint effects of global, political, and organizational conditions on fossil-fueled plants' $\mathrm{CO}_{2}$ emissions. Findings reveal that hyperpolluters' emission rates are a function of four distinct causal recipes, which we label coercive, quiescent, expropriative, and inertial configurations, and these same sets of conditions also increase plants' emission levels.

Keywords: climate change; organizations; world society; world-system; electricity

Citation: Grant, Don, Andrew $\mathrm{K}$. Jorgenson, and Wesley Longhofer. 2018. "Pathways to Carbon Pollution: The Interactive Effects of Global, Political, and Organizational Factors on Power Plants' $\mathrm{CO}_{2}$ Emissions." Sociological Science 5: 58-92.

Received: November 15, 2017

Accepted: December 8, 2017

Published: January 25, 2018

Editor(s): Jesper Sørensen, Sarah Soule

DOI: $10.15195 / \mathrm{v} 5 . \mathrm{a} 4$

Copyright: (C) 2018 The Author(s). This open-access article has been published under a Creative Commons Attribution License, which allows unrestricted use, distribution and reproduction, in any form, as long as the original author and source have been credited. (0)(1)
CimATE change is arguably the greatest threat to society as power plants, the single largest human source of heat-trapping pollution, continue to emit massive amounts of carbon into the atmosphere. But which fossil fuel power plants generate the most carbon pollution and what global, political, and organizational features do they have in common?

Most sociological research on the determinants of carbon pollution has focused on the effects of different international relationships on emission outcomes (Dunlap and Brulle 2015; Rosa and Dietz 2012). In particular, there is an ongoing debate over whether a nation's emissions are a function of its location in the core, semiperiphery, and periphery zones of the world-system (Podobnik 2006; Roberts and Parks 2007) or its embeddedness in world society, reflected in its participation in international environmental organizations (Hironaka 2014; Schofer and Hironaka 2005). Others have faulted these global accounts for neglecting middle-range factors (Bergara, Henisz, and Spiller 1998; Prechel and Zheng 2012; Rudel 2009; Shwom 2009). According to them, pollution outcomes are primarily the result of national politicallegal systems that regulate the power relations between businesses, the state, and the citizenry.

None of these approaches, however, have studied the organizations through which electricity and carbon pollution are actually produced-power plants-and disparities in their propensity to pollute (Freudenburg 2005). In particular, they have yet to examine how global and political structures combine with the organizational properties of plants to generate heat-trapping pollutants (Perrow 2010; 
Perrow and Pulver 2015). Climate-disrupting emissions are too complex a problem to be analyzed by one framework alone. To address this problem effectively, we need to better understand where and why these polluting activities occur. As it stands, not only have scholars made little progress integrating competing perspectives on carbon pollution, but our understanding of the social structural profiles of hyperpolluting power plants and the mechanisms that possibly explain their environmental behavior remains limited.

We seek to remedy this situation by sketching what we label a "pathways to carbon pollution" framework. According to our framework, power plants are the chief sites through which various global, political, and organizational structures $^{1}$ interact $^{2}$ to generate multiple routes to carbon pollution. Some of these pathways-which we refer to as coercive and quiescent configurations-enhance plants' ability to externalize their pollution by neutralizing and manipulating potential sources of resistance, whereas others-which we call expropriative and inertial configurations-inhibit plants' ability to curb emissions by subjecting them to opportunistic behavior and forces of inertia. To evaluate our framework, we use a novel data set on the $\mathrm{CO}_{2}$ emissions and structural attributes of nearly 20,000 fossil fuel power plants in 148 countries compiled and provided to us by the Center for Global Development (CARMA.org). We also employ multilevel regression techniques (Rabe-Hesketh and Skrondal 2008) in conjunction with innovative fuzzy-set Qualitative Comparative Analysis (fsQCA) methods (Ragin and Fiss 2008; Ragin 2000) that can identify which combinations of factors are associated with a given outcome. Using these data and methods, we determine whether power plants' high $\mathrm{CO}_{2}$ emission rates are a function of coercive, quiescent, expropriative, or inertial configurations. We also test these configurations' effects net of other controls and their impact on plants' emission levels. ${ }^{3,4}$ We conclude by discussing how our approach can help integrate the growing number of social scientific perspectives on the human dimensions of pollution and environmental change as well as advance research on the determinants of organizations' environmental performance.

\section{Background}

\section{Global Explanations of Carbon Pollution}

Greenhouse gas emissions from the electricity sector are projected to double and perhaps even triple from 2010 baseline levels by 2050 unless steps are taken to decarbonize energy (Intergovernmental Panel on Climate Change 2014). In light of these and other forecasts, social scientists have investigated the causes of crossnational differences in electricity-based $\mathrm{CO}_{2}$ emission outcomes, such as those shown in columns 1 and 2 of Table 1. Led by structural human ecologists (Dietz 2015; Dietz, Rosa, and York 2010; York, Rosa, and Dietz 2003), this body of research initially focused on cross-national differences in carbon pollution and emphasized the effects of population growth, wealth, and other indicators of national energy consumption (see also Jorgenson and Clark 2012). More recently, scholars have redirected their attention to global structures that shape where and how energy is 
Table 1: Top $\mathrm{CO}_{2}$-emitting countries (2009).

\begin{tabular}{|c|c|c|c|c|c|c|}
\hline $\begin{array}{l}\text { Total } \mathrm{CO}_{2} \\
\text { Emissions } \\
\text { Rank by } \\
\text { Country }\end{array}$ & $\begin{array}{c}(1) \\
\text { Electricity } \\
\text { Sector's } \\
\mathrm{CO}_{2} \\
\text { Emission } \\
\text { Level } \\
\text { (Millions of Tons) }\end{array}$ & $\begin{array}{c}\text { Electricity } \\
\text { Sector's } \\
\mathrm{CO}_{2} \\
\text { Emission } \\
\text { Rate }\end{array}$ & $\begin{array}{c}(3) \\
\text { Top 5\% } \\
\text { Share of } \\
\text { Sector's } \\
\text { Total } \\
\mathrm{CO}_{2} \\
\text { Emissions }\end{array}$ & $\begin{array}{c}(4) \\
\text { Top 5\% } \\
\text { Share of } \\
\text { Sector's } \\
\text { Total } \\
\text { Electricity } \\
\text { Generated }\end{array}$ & $\begin{array}{l}(5) \\
\text { Emission } \\
\text { Rate } \\
\text { Ratio of } \\
\text { Top 5\% to } \\
\text { Average } \\
\text { Plant }\end{array}$ & $\begin{array}{l}(6) \\
\% \\
\text { Elec- } \\
\text { tricity } \\
\text { from } \\
\text { Fossil } \\
\text { Fuels }\end{array}$ \\
\hline 1. China $(1,134)$ & 2,840 & 823 & 37 & 31 & 1.92 & 80 \\
\hline 2. United States $(2,592)$ & 2,320 & 609 & 75 & 47 & 1.42 & 69 \\
\hline 3. India (745) & 694 & 835 & 75 & 58 & 2.85 & 81 \\
\hline 4. Russia (548) & 542 & 587 & 45 & 29 & 1.41 & 65 \\
\hline 5. Japan $(2,199)$ & 387 & 405 & 97 & 63 & 1.83 & 60 \\
\hline 6. Germany $(1,072)$ & 303 & 569 & 98 & 64 & 5.11 & 63 \\
\hline 7. Canada (460) & 101 & 209 & 94 & 24 & 2.10 & 25 \\
\hline 8. South Korea (214) & 233 & 549 & 84 & 52 & 1.63 & 65 \\
\hline 9. Iran (140) & 121 & 647 & 44 & 43 & 1.21 & 97 \\
\hline 10. United Kingdom(835) & 175 & 497 & 96 & 75 & 1.92 & 66 \\
\hline 11. Saudi Arabia (208) & 161 & 800 & 53 & 56 & 0.83 & 99 \\
\hline 12. South Africa (146) & 225 & 957 & 21 & 22 & 2.19 & 95 \\
\hline 13. Mexico (179) & 118 & 497 & 57 & 44 & 1.32 & 83 \\
\hline 14. Brazil (158) & 24.9 & 52 & 85 & 6 & 4.52 & 7 \\
\hline 15. Australia (443) & 219 & 907 & 93 & 83 & 2.07 & 93 \\
\hline 16. Indonesia (534) & 111 & 793 & 81 & 71 & 1.21 & 89 \\
\hline 17. Italy (569) & 137 & 495 & 94 & 74 & 3.65 & 76 \\
\hline 18. France (528) & 44.6 & 114 & 90 & 12 & 3.48 & 14 \\
\hline 19. Spain (502) & 87.3 & 337 & 96 & 56 & 4.31 & 32 \\
\hline 20. Taiwan (120) & 139 & 661 & 79 & 60 & 2.12 & 79 \\
\hline
\end{tabular}

Data come from the Center for Global Development's CARMA data file. The table is taken from Grant, Jorgenson, and Longhofer (2013). Figures in parentheses are the number of power plants in a country tracked by CARMA.

produced (Shwom 2011). They disagree, though, over which of these structures are most consequential.

On the one hand, world-systems scholars argue that nations' positions in the global economic hierarchy locks them into different trajectories of fossil fuel use (Jorgenson, Dick, and Mahutga 2007; Roberts and Parks 2007). From their perspective, all countries are organized into a stratified political-economic interstate system that is largely controlled by wealthy and geopolitically powerful "core" nations (Chase-Dunn and Grimes 1995). These core nations, which include the United States, Japan, the majority of Western European countries, and most recently BRIC (Brazil, Russia, India, and China), substantially control trade and financial relationships with other nations. Core nations are also the predominant global producers (and consumers) and extract the basic resources they need for production 
(e.g., fossil fuels) from-as well as export their waste to-poorer peripheral nations. Semiperipheral nations are intermediaries between the core and periphery, typically undergoing rapid industrialization. It follows that as the global economy expands, the relationship between development and environmental harms will remain constant and possibly intensify in magnitude through time (Podobnik 2006). These strong and potentially intensifying relationships between environmental harms and development are largely driven by the structure of global production and trade networks as well as foreign investment (Jorgenson et al. 2007; Roberts and Grimes 2002). ${ }^{5}$

On the other hand, world society scholars contend that a nation's willingness to counter carbon pollution depends on its cultural integration into a global proenvironmental order (Longhofer and Schofer 2010; Schofer and Hironaka 2005). According to them, nation-states are nested in a global environmental regime composed of shared norms and a variety of global institutions that compels them to recognize the importance of environmental sustainability to their long-term survival (Frank, Hironaka, and Schofer 2000; Hironaka 2014; Schofer and Hironaka 2005). Despite a great deal of loose coupling between adopted policies and actual practices (Bromley and Powell 2012), scholars in this tradition find that stronger ties to world society are associated with improved environmental outcomes at the national level, including reductions in carbon emissions and other environmental harms (Hironaka 2014; Schofer and Hironaka 2005; Shandra et al. 2009). ${ }^{6}$ They suggest further that world society prods industry - in an effort to be seen as more legitimate in light of growing environmental concerns - to become more ecologically rational (i.e., to weigh the costs and benefits of environmental degradation and to strive to reduce externalities in the same way that modernization also compels industry to be more economically rational). Proponents of this perspective, then, would expect industries whose nations are more embedded in the global environmental regime, as indicated by their participation in environmental international nongovernmental organizations (EINGOs) and treaties, to be more likely to reduce their pollution through various reforms and improvements.

\section{Political Explanations of Carbon Pollution}

Other researchers note that although world society scholars and to a lesser extent world-systems researchers acknowledge that the nation-state is still relevant in an era of globalization, neither focus on the "stuff of politics" (see Buttel 2004) nor the arrangements for resolving issues like energy-environment conflicts. Consequently, they overlook how different national political systems may determine carbon pollution (see also Prechel and Zheng 2012; Rudel 2009). According to these critics, the effects of global factors are overshadowed by the unity of the business class, the likelihood of government regulation, and the public's awareness of environmental issues at the national level. Shwom (2011) shows, for example, that efforts to make U.S. manufacturers improve the energy efficiency of their home appliance products have often been decided by the federal government's willingness to threaten regulation and its openness to pressure from business coalitions and energy advocates. Prechel and Istvan's (2016) study of the U.S. electrical industry likewise attests to 
how national political-legal arrangements condition the release of toxins (see also Dietz et al. 2015).

Especially germane to our worldwide study of electricity-based $\mathrm{CO}_{2}$ emissions, Bergara et al. (1998:19-20) argue that because electric utilities require huge sunk investments, operate through economies of scale, and provide energy services to large populations, political actors have an incentive to behave opportunistically and expropriate utilities' assets (see also Henisz 2002; Henisz, Zelner, and Guillén 2005). This is less likely to happen, though, in nations where there are formal or informal government procedures required for regulatory decision-making, the judiciary has the tradition or authority to review administrative decisions, and the government's horizon is relatively long. These checks and balances provide safeguards against unilateral changes to the rules governing the electricity sector. Hence, they keep transaction costs down and give capitalists and public company managers fewer financial incentives to externalize their plants' pollution.

\section{Organizational Explanations of Carbon Pollution}

Organizational scholars argue that because global and political accounts of carbon pollution focus on cross-national differences in emissions, they obscure the fact that some facilities emit vastly more pollutants than others even after taking into account differences in their productivity (Freudenberg 2005; Jorgenson, Longhofer, and Grant 2016). As column 3 of Table 1 shows, within the electricity sectors of the countries that release the most carbon dioxide, emission levels can vary greatly across utility facilities. For instance, in China's electricity sector, the top 5 percent of polluting power plants account for more than a third of that nation's total electricitybased $\mathrm{CO}_{2}$ discharges. In the next two most heavily polluting countries-the United States and India-the top 5 percent are responsible for nearly double that amount (or about three-fourths of their sectors' total emissions). And in a near majority of the remaining countries listed, the top 5 percent account for 90 percent or more of all carbon emissions from the electricity sector. Although the uneven distribution of emissions partially reflects the fact that the top 5 percent also generate a large share of their sector's total electricity (see column 4), it is still the case that, except in Saudi Arabia, these plants emit more $\mathrm{CO}_{2}$ than one would expect given the amount of electricity they generate (see column 5). In the United States, for example, the worst polluters generate 47 percent of the country's electricity but are responsible for 75 percent of all electricity-based $\mathrm{CO}_{2}$ emissions and have emission rates 42 percent higher than the average U.S. power plant.

The fact that the electricity sector is responsible for the lion's share of carbon pollution and plants with the highest emission levels also tend to have higher-thanaverage emission rates has convinced international bodies like the United Nations Framework Convention on Climate Change's Conference of the Parties (COP 21) that setting targets for plants' carbon intensities is the most effective means to a low-carbon future (see also United Nations Framework Convention on Climate Change 2007). Whether this is the optimal strategy is open to debate, but it does beg the question: why do some power plants have higher $\mathrm{CO}_{2}$ emission rates than others? Obviously, the type of inputs used by plants may be an important factor. 
That a relatively small percentage of electricity is generated from fossil fuels, for example, in countries such as Canada, Brazil, and France would suggest that their top 5 percent of polluters are among the few that use such fuels, and differences in these plants' carbon intensities may be a function of whether they primarily use coal, natural gas, or oil (see column 6 of Table 1). In addition, plants that can produce more electricity may benefit from economies of scale that enable them to invest in better pollution equipment.

It is doubtful, however, that the environmental performance of power plants is solely a function of their inputs and potential outputs. Rather, as organizational scholars suggest, the structural properties of facilities themselves likely play determinative roles. For example, Perrow (2010) contends that size, the most studied variable in the literature on organizational structure (Scott 1992:258-67), is a major determinant of environmental degradation in modern society, including carbon pollution (see also Grant, Jones, and Bergesen 2002). According to him and others, size concentrates power and thus enables corporations to maintain the status quo through their control over markets, ability to shape public policy, and framing of environmental issues. In the case of electricity, plants whose parent firms own a sizeable share of a country's existing production capacity are well positioned to leverage those forms of structural, instrumental, and discursive power to resist pressures to change and adopt more advanced pollution equipment (see Grant et al. 2002; Prechel and Istvan 2016; Prechel and Touche 2014).

Similarly, organizational ecologists argue that the oldest members of organizational populations are especially subject to inertia (Hannan and Freeman 1989). Change is not only difficult and rare for these organizations but hazardous as well because their survival often depends on their predictability (Hannan and Freeman 1989). Older organizations, therefore, not only have more vested interests in established pollution practices but also are prone to ossify.

Unfortunately, because they tend to view organizations as the "ultimate environmental destroyers" (Perrow 2010), organizational scholars have been slow to acknowledge the possibility that the structural properties of organizations may combine with those of their external environments to shape emission outcomes (though that is beginning to change as we note below). In that respect, they resemble world society, world-system, and political institutions researchers who treat their various structures as competing predictors of carbon pollution.

It follows from the review above that to advance our understanding of the structural determinants of electricity-based $\mathrm{CO}_{2}$ emissions, we need an alternative conceptual framework that addresses how global, political, and organizational factors interact to shape power plants' emission outcomes. Toward that end, in the next section we draw on the literature on organizational configurations to sketch a theory of the pathways to carbon pollution.

\section{Theory: Pathways to Carbon Pollution}

A configurational perspective on organizations (Fiss 2007; Fiss, Cambré, and Marx 2013) suggests that to fully understand the impacts of organizations, one needs to study the structures that differentiate them and the effects of those structures on 
outcomes like pollution. These structures need not exist at the same level of analysis but can combine both within and across levels (Crilly 2013). Indeed, it is through the discovery of these complementarities that scholars can begin to integrate insights from otherwise competing explanations of an organizational outcome. A configurational perspective thus conceives organizations as constellations of interconnected internal and external structures. In this view, organizations' structures are not entirely modular and thus should not be studied as individual predictors. Instead, organizations are made up of different bundles of structures; scholars should therefore show how certain structural profiles are related to outcomes. A configurational perspective also rejects the notion of unifinality, which suggests that there is one optimal configuration leading to an outcome. Instead, it embraces the concept of equifinality, which states that two or more configurations can be equally effective in producing an outcome.

Although prior research on carbon pollution has conceived global, political, and organizational conditions as alternative explanations, they are not fundamentally contradictory because they highlight different structural properties. It is quite possible, therefore, that they work in concert to produce emission outcomes, as a configurational framework would expect. Indeed, scholars have begun exploring ways of integrating insights from different perspectives to provide more complete and nuanced understandings of the determinants of carbon pollution. For example, whereas world-system scholars continue to take issue with world society researchers' claim that worldwide norms are capable of offsetting the pollution created by global capitalism, some concede that nations that exclude transnationally organized civil society groups should have a more difficult time than those with ties to them, suppressing the environmental harms associated with trade regimes (Jorgenson, Dick, and Shandra 2011; Shorette 2012; see also Buttel 2000). Similarly, some scholars who emphasize the agency of individual organizations and how their internal dynamics affect carbon emissions also acknowledge that the larger economic, cultural, and governance structures in which organizations are embedded can simultaneously influence pollution behavior (Marquis, Toffel, and Zhou 2016; Perrow and Pulver 2015).

Drawing on recent literature on environmental degradation and social structures, we extend these lines of inquiry by hypothesizing four ways that global, political, and organizational factors might interact to generate carbon pollution and suggest the mechanisms that explain their effects (as indicated by the labels we assign to them). Configurations that enhance plants' tendency to pollute come in two basic forms that we label coercive and quiescent configurations. Those that inhibit plants' capacity to act in environmentally sustainable ways also come in two varieties that we call expropriative and inertial configurations. We briefly discuss these four configurations in turn.

Coercive configurations resemble patterns that environmental inequality scholars suggest present polluters with the least resistance (Bullard 1993; Schelly and Stretesky 2009). According to their research, ecodestructive facilities are often found in settings that not only have abundant market opportunities but whose residents are socially isolated and denied access to procedural equity. Applied to our study, this would suggest that in core nations that are disengaged from global environmen- 
tal norms and whose governments lack a system of political checks and balances (e.g., the United Arab Emirates, which according to Clark and Beckfield [2009] has recently entered the core), utilities are able to engage in what Weber ([1922] 1978) calls coercive power and impose their polluting activities on others.

Quiescent configurations mirror other scenarios suggested by environmental inequality scholars that keep citizens silent about pollution problems (Shriver, Adams, and Messer 2014). Under these scenarios, plants also seek out promising markets whose residents are socially isolated. But unlike the case with settings that offer the least resistance, the economic power of elites is decisive. That is, facilities owned by companies that control a large share of a market are able to forestall environmental grievances and mollify publics who depend on their products or services. It follows that the power plants most able to pollute by rendering the public compliant are those located in core nations that are disengaged from global environmental norms and whose parent firms dominate a nation's utility sector. These plants exercise an influence akin to what Weber ([1922] 1978) calls manipulative power.

Expropriative configurations correspond with circumstances that, according to transaction cost researchers, make utilities highly susceptible to opportunistic behavior by outside actors (Bergara et al. 1998; Henisz 2002). As discussed above, where there are few political constraints in the form of checks and balances, judiciary review, decentralized decision-making, et cetera, governments are apt to expropriate the assets of power stations for political gains. Although coercion and expropriation are related, the latter is understood here as differing in that it involves a government "taking" without adequate compensation. Large, well-established utilities are especially desirable targets for seizure because they service numerous citizens and have more accumulated knowledge about electricity production. Because the threat of being expropriated increases transaction costs, power plants in nations lacking a system of political checks and balances whose parent firms dominate a nation's utility sector and who are old should be especially inclined to pollute.

Inertial configurations relate to conditions that world-system scholars and organizational ecologists suggest induce ossification. World-system scholars (Chase-Dunn and Grimes 1995) contend that although core countries initially experience phases of growth and expansion, they inevitably go through phases of decline and decay. Organizational ecologists (Hannan and Freeman 1989) add that larger and older organizations suffer from increasing calcification as a result of bureaucratization and other time-dependent processes. Moreover, both types of organizations lose their ability to respond quickly or appropriately to changing conditions and their technologies are prone to obsolescence. This suggests that power plants should have the most difficulty reducing their discharges when they possess these three inertial conditions simultaneously-i.e., they are located in the core zone; are part of a large, dominant parent firm; and are old.

Restated as formal hypotheses, we test the following in the subsequent analyses:

1. There is no single structural pathway to carbon pollution. Instead, the power plants with the highest $\mathrm{CO}_{2}$ emission rates are those (a) located in the world-system's core zone and in nations that are disengaged from global environmental norms and lack a system of political checks and 
balances (coercive configurations), (b) located in the world-system's core zone and in nations that are disengaged from global environmental norms and owned by dominant utilities (quiescent configurations), (c) located in nations lacking a system of political checks and balances and owned by dominant utilities and are old (expropriative configurations), or (d) located in the world-system's core zone and owned by dominant utilities and are old (inertial configurations).

2. These four pathways should significantly affect plants' emission rates net of other controls.

3. The underlying mechanisms that explain why plants on the four pathways have high emission rates are also relevant to their emission levels and therefore should have significant, positive net effects on both outcomes.

\section{Data and Methods}

To assess the hypotheses, we constructed a data set that includes indicators of fossil fuel power plants' $\mathrm{CO}_{2}$ emissions in 2004 and 2009, their nations' position in the world-system and proenvironmental world society, national political-legal systems, their organizational characteristics, and other potentially relevant factors. The primary data source for this project is the Center for Global Development's Carbon Monitoring for Action (CARMA) data file. ${ }^{7}$

CARMA draws on three data sets: plant-level emissions reports from the United States, the European Union, Canada, and India; global plant- and company-level data from Platt's World Electric Power Plants Database; and country-specific power production data from the U.S. Energy Information Agency (Wheeler and Ummel 2008). For nonreporting plants, CARMA estimates emissions using a statistical model fitted to data for the reporting plants and detailed data from the other two sources on plant-level engineering specifications. Thus, CARMA provides information on the environmental performance of virtually every country's power plants. $^{8}$

In addition to providing information on the carbon emissions of roughly 20,000 fossil fuel power plants from around the world, CARMA assigns to each plant a unique Platts identification code. This code enables a researcher to append additional information gathered by Platts and other sources on the organizational characteristics of each plant and its parent firm. CARMA also provides the addresses and coordinates ${ }^{9}$ of plants that can be used to append other data on plants' host countries, including whether they are located in the core, semiperiphery, or periphery; their memberships in EINGOs and treaties; and their political institutions.

The unit of analysis is the plant and the constructed data set consists of 19,525 cases. We chose this unit of analysis because power plants are the sites where electricity is actually produced and a quarter of all anthropogenic $\mathrm{CO}_{2}$ emissions occur. Power plants are also primary channels through which various global, political, and organizational structures interact to generate environmental impacts, and to try to study the effects of plants' characteristics on emissions using aggregated data 
(e.g., at the national level) would be subject to misinterpretation and, in particular, the ecological fallacy.

The electrical power sector is divided into four basic processes: electricity retailing, electricity distribution, electric power transmission, and electricity generation, which we are primarily interested in. Generating stations and the infrastructure for the transmission and distribution of electricity may be owned and operated by one organization or several organizations that provide and manage different parts of the systems. These organizations can range from government entities (e.g., city or municipally owned companies) and private or investor-owned businesses to cooperatives run by customers. Where there is a tight relationship between utilities and government, utilities can become quasi monopolies and be prone to price gouging, requiring state officials to implement price controls.

\section{Dependent Variables}

Our first dependent variable, obtained from the CARMA data set, is $\mathrm{CO}_{2}$ emission rate, or total kilograms of carbon dioxide emitted by a plant divided by the net megawatt hours of electricity it generated in the year 2009. We focus on this outcome because it is the one most often used when regulating greenhouse gases (Ellerman and Sue 2003). Also, the United Nations and other international organizations agree that reducing the carbon intensity of electricity production is a viable strategy for mitigating climate change and especially for developing countries that still have large and growing energy needs (United Nations Framework Convention on Climate Change 2007). Because this measure of emissions is highly skewed, we use a logarithmic transformation (i.e., logged) of it in our analyses. We also examine whether the configurations we hypothesize will have a positive impact on emission rates have the same effect on plants' (logged due to skewness) emission levels (i.e., total kilograms of carbon dioxide emitted by a plant), our second dependent variable.

\section{Key Independent Variables}

Our measure of world-system position is based on a principal components analysis with a varimax rotation of categorical and continuous measures used in past research. ${ }^{10}$ Specifically, the analysis included dummies for location in the core, semiperiphery, and periphery (taken from Clark and Beckfield's [2009] trichotomous country-level scheme ${ }^{11}$ ) as well as measures of individual nations' exports and foreign direct investment. As shown in Table 2, the analysis produced a twofactor solution, with core and periphery loading highly on the first factor that captured proximity to the world-system's core. Both items were combined in a scale that showed very good reliability $(\mathrm{a}=0.782) .{ }^{12}$ Exports and foreign direct investment loaded on the second factor, but when they were combined in a scale, its reliability proved to be poor $(\mathrm{a}=0.379)$. Therefore, rather than use this second scale in our fuzzy-set analysis, we incorporated exports and foreign direct investment in our regression models as controls.

Our measure of normative engagement is also based on a factor analysis (see Table 3) that yielded a one-factor solution that includes five items used regularly 
Table 2: Principal component factor analysis of world-system position.

\begin{tabular}{lrr}
\hline Survey Item & Factor 1 & Factor 2 \\
\hline Core & 0.944 & 0.027 \\
Semiperiphery & -0.040 & -0.001 \\
Periphery & -0.853 & -0.024 \\
Exports & 0.257 & 0.841 \\
Foreign Direct Investment & -0.162 & 0.880 \\
Eigenvalue & & \\
Portion of Variance Explained by Eigenvalue & 1.712 & 1.481 \\
\hline
\end{tabular}

in world society research: national memberships in EINGOs, ${ }^{13}$ comprehensive environmental law, environmental impact legislation, environmental ministry, and number of ratified international environmental treaties. These items were combined in a scale with high reliability $(\mathrm{a}=0.720)$.

To determine the effects of political checks and balances, we use an updated version of Bergara et al.'s (1998) index of political constraints (https://mgmt.wharton.upenn.edu/faculty/heniszpolcon/polcondataset/). The latter is derived from three component variables: judicial effectiveness (e.g., median tenure of supreme or high court justices), formal constraints on executive discretion (e.g., the existence of federal units or a bicameral legislature elected under independent voting rules), and informal constraints on executive discretion (e.g., quality of the bureaucracy). High scores on this measure (which theoretically ranges from 0 to 1 but actually peaks at 0.7 ) indicate that a nation's government more resembles a decentralized decision-making system, and low scores indicate a centralized one. ${ }^{14}$

Our two organizational measures were derived from a factor analysis of several indicators of plant age, size, and ownership type. As shown in Table 4, the analysis produced a two-factor solution with three items of size and ownership (percent of a nation's electrical capacity owned by a plant's parent firm, percent of a nation's electrical output produced by a plant's parent firm, and ownership by a utility ${ }^{15}$ ) loading on the first factor, which seems to measure whether a plant was part of a dominant utility, and two items gauging plant age loading highly on the second factor. The reliabilities for the two resulting scales are, respectively, 0.803 and 0.961 . One item, private ownership, did not load on either of the factors and is included as a control in the regression analyses.

\section{Controls}

We control for whether a plant's fuel source is primarily coal $(1=\text { coal })^{16}$ or primarily gas $\left(1=\right.$ natural gas), its electrical capacity (nameplate capacity), ${ }^{17}$ and whether it is under private ownership ( 1 = private, independent power plant $).{ }^{18} \mathrm{We}$ also control for macrolevel factors shown in prior research to shape anthropogenic $\mathrm{CO}_{2}$ emissions, including national-level measures of population size, wealth (gross 
Table 3: Principal component factor analysis of engagement with world environmental norms.

\begin{tabular}{lc}
\hline Survey Item & Factor 1 \\
\hline EINGOs & 0.701 \\
Comprehensive Environmental Law & 0.652 \\
Environmental Impact Legislation & 0.748 \\
Environmental Ministry & 0.724 \\
Environmental Treaties & 0.522 \\
Eigenvalue & 2.271 \\
Portion of Variance Explained by Eigenvalue & 0.454 \\
\hline
\end{tabular}

domestic product [GDP] per capita), average price of electricity, whether a carbon tax $(1=$ yes) has been adopted in a plant's country, exports ( percent of GDP), and foreign direct investment ( percent of GDP) (Jorgenson and Clark 2012; York et al. 2003). And to capture other conditions from the past that might influence plants' present environmental performance, we include indicators of our two emission measures for the year 2004 in some of the regression models. ${ }^{19}$

Table 5 lists all included variables and their sources. When conducting our regression analyses (discussed below), all nonbinary independent variables and controls are logged to assess their multiplicative effects, a well-established practice in social science research on carbon emissions (Rosa and Dietz 2012). With the exception of prior emission rate and emission level as well as our measure of proximity to the world-system's core zone that includes items covering years up to 2000, which we argue is the best available estimate of the international trade regime during the period of study, we measure all of our predictors in the year 2009.

\section{Methods}

The evaluation of our hypotheses requires a mixed methods strategy. To assess our first hypothesis that global, political, and organizational factors combine in complex ways to create multiple pathways to high $\mathrm{CO}_{2}$ emission rates, we need a method capable of testing higher-order interactions. To assess our second and third hypotheses that these pathways affect emission rates as well as emission levels net of controls, we need a method that can test the effects of higher-order interactions while also accounting for other potential causes.

fsQCA is especially well suited to evaluate higher-order interactions and determine which of several possible combinations of factors are most relevant for an outcome (Ragin 2000). Regression techniques can evaluate interactions as well, but it is difficult to interpret anything beyond simple two-way interactions within a regression format. Regression also presumes that a statistically significant interaction can be generalized to all cases under investigation when, in fact, it may only occur in some cases. Multilevel regression, though, can do something that fsQCA cannot, which is test the effects of higher-order combinations net of other controls 
Table 4: Principal component factor analysis of organizational factors.

\begin{tabular}{lcr}
\hline Survey Item & Factor 1 & Factor 2 \\
\hline Average Generator Age & 0.004 & 0.981 \\
Maximum Generator Age & 0.038 & 0.977 \\
Private Ownership & 0.017 & -0.107 \\
Utility & 0.483 & -0.011 \\
Share of Electrical Capacity & 0.961 & 0.018 \\
Share of Electrical Output & 0.960 & 0.019 \\
Eigenvalue & & \\
Portion of Variance Explained by Eigenvalue & 2.083 & 1.929 \\
\hline
\end{tabular}

and capture fixed aspects of the units within which cases are situated. Therefore, below we describe fsQCA and multilevel regression techniques and outline how they are employed to test our hypotheses.

\section{fsQCA}

Qualitative Comparative Analysis (QCA) and its fuzzy-set variant (fsQCA) treat cases as combinations of attributes and use Boolean algebra to derive simplified expressions of combinations associated with an outcome (Ragin 2000). For example, given an outcome set $\mathrm{Y}$ and predictors $\mathrm{A}$ and $\mathrm{B}, \mathrm{QCA}$ determines which combinations of $\mathrm{A}$ and $\mathrm{B}$ (i.e., $\mathrm{AB}, \mathrm{Ab}, \mathrm{aB}, \mathrm{ab}$ ) are most likely to produce $\mathrm{Y}$. In a $\mathrm{QCA}$ framework, the term "set" is used instead of "variable" to stress the idea that each variable has been transformed to represent an individual case's level of membership in a given condition (e.g., a facility's membership in the set of organizations with high emission rates).

The combination of individual "sets" - for example, facilities that are located in the core zone and countries with few political checks and balances-is then referred to as a "configuration." Sets are labeled with uppercase and lowercase letters. When working with crisp sets or sets that are all dichotomous indicators, uppercase letters signify 1 (fully in A) and lowercase letters signify 0 (fully out of A). When working with fuzzy sets or sets that can take on a value between 0 and 1, uppercase letters mean the level of set membership (e.g., the value of A) and lowercase letters mean 1 minus the set membership (e.g., $1-\mathrm{A}$ ). In the case of fsQCA, then, individual organizations can be more or less a member of a particular set (e.g., 0.33 would indicate something like "more out than in, but still somewhat in" the set, whereas 0.75 would signify something like "more in than out, but not entirely in" the set). Although some variation is lost in "fuzzifying" measures, this limitation is more than offset by fsQCA's ability to assess higher-order interactions. Combining fuzzy sets into configurations is usually done using the minimum operator, so $\mathrm{AB}=\min (\mathrm{A}, \mathrm{B})$ or $\mathrm{aB}=\min \{(1-\mathrm{A}), \mathrm{B}\}$. For example, a case with a fuzzy score of 0.6 on $A$ and 0.3 on $B$ would be said to have a fuzzy score of 0.3 in the 
Table 5: Variable summary.

\begin{tabular}{|c|c|c|}
\hline Variable & Source (Year) & $\begin{array}{l}\text { Mean / Standard } \\
\text { Deviation }\end{array}$ \\
\hline \multicolumn{3}{|l|}{ Dependent Variables } \\
\hline $\mathrm{CO}_{2}$ Emission Rate & CARMA (2004 and 2009) & 768.84 / 309.91 \\
\hline $\mathrm{CO}_{2}$ Emission Level & CARMA (2004 and 2009) & $518,639 / 1,835,012$ \\
\hline \multicolumn{3}{|l|}{ Key Independent Variables } \\
\hline \multicolumn{3}{|l|}{ Global } \\
\hline Core (Fuzzified) & Clark and Beckfield (2000) & $0.84 / 0.35$ \\
\hline \multirow[t]{2}{*}{ Normative Engagement (Fuzzified) } & $\begin{array}{l}\text { Union of International Associations } \\
\text { (2009); ECOLEX; United Nations }\end{array}$ & \\
\hline & Environment Programme & $0.51 / 0.29$ \\
\hline \multicolumn{3}{|l|}{ Political } \\
\hline $\begin{array}{l}\text { Political Checks and Balances } \\
\text { (Fuzzified) }\end{array}$ & Henisz (2009) & $0.47 / 0.30$ \\
\hline \multicolumn{3}{|l|}{ Organizational } \\
\hline Dominant Utility (Fuzzified) & S\&P Global Platts (2009) & $0.43 / 0.26$ \\
\hline Plant Age (Fuzzified) & S\&P Global Platts (2009) & $0.47 / 0.31$ \\
\hline \multicolumn{3}{|l|}{ Controls } \\
\hline \multicolumn{3}{|l|}{ Plant Characteristics } \\
\hline Primarily Coal $(1=$ Coal $)$ & S\&P Global Platts (2009) & $0.14 / 0.35$ \\
\hline Primarily Gas (1 = Natural Gas) & S\&P Global Platts (2009) & $0.41 / 0.49$ \\
\hline Electrical Capacity & S\&P Global Platts (2009) & 164.72 / 438.11 \\
\hline Capacity Utilization Rate & S\&P Global Platts (2009) & $0.33 / 0.24$ \\
\hline Private Ownership (1 = Yes) & S\&P Global Platts (2009) & $0.13 / 0.34$ \\
\hline Prior $\mathrm{CO}_{2}$ Emission Rate & CARMA (2004) & $740.75 / 401.96$ \\
\hline Prior $\mathrm{CO}_{2}$ Emission Level & CARMA (2004) & 549,793 / 1,918,063 \\
\hline \multicolumn{3}{|l|}{ Country Characteristics } \\
\hline Population & World Bank (2009) & $2.06 \mathrm{e}+08 / 3.52 \mathrm{e}+08$ \\
\hline Wealth (GDP per Capita) & World Bank (2009) & 22,947 / 17,094 \\
\hline Price of Electricity (US Cents / kWh) & Rosa and Dietz (2012) & $0.19 / 0.08$ \\
\hline Carbon Tax (1 = yes) & International Energy Agency (2009) & $0.05 / 0.22$ \\
\hline Exports (\% of GDP) & World Bank (2009) & $20.15 / 22.87$ \\
\hline Foreign Direct Investment (\% of GDP) & World Bank (2009) & $2.37 / 3.49$ \\
\hline
\end{tabular}

configuration $\mathrm{AB}$. Unlike variable-based methods that are founded on the notion of unifinality and seek to estimate a single recipe for all cases under examination, QCA methods explicitly take the idea of equifinality into account, allowing different subsets to produce the same outcome through different pathways. ${ }^{20}$ Therefore, QCA "solutions" can contain multiple "pathways," "configurations," or "recipes," 
with each pathway specifying a combination of presence and/or absence on a set of predictors.

In our fsQCA analyses, we convert the dependent and key independent variables into fuzzy scores because several of them cannot be easily categorized as full membership (1) or nonmembership (0) in a set, which would be required if using conventional QCA techniques. For example, it is not immediately obvious what constitutes a high $\mathrm{CO}_{2}$ emission rate. fsQCA addresses this type of problem by having researchers recode their measures continuously as degrees of membership (or in the interval between 0 and 1) based on theoretical or substantive knowledge. Key to this coding procedure is deciding which cases are the most ambiguous or should be assigned a value of 0.5 . Once variables are calibrated, fsQCA can then examine not only the level of overlap between independent variables but also the extent to which certain combinations of independent variables overlap or are a subset of the dependent variable (if $X$, then $Y$ ).

The fit of these solutions is described in terms of their consistency and coverage. Consistency is a measure of how often the outcome is present when the conditions in a given pathway are met (the proportion of cases in $X$ that are also in $Y$ ). A high consistency score (near 1) indicates that a solution term is near to being sufficient for an outcome. Coverage measures how often a certain pathway is present when the solution is present (the proportion of cases in $\mathrm{Y}$ that are also in $\mathrm{X}$ ). A high coverage score indicates that a certain pathway is relevant (i.e., has empirical weight). ${ }^{21}$

Regulatory agencies like the Environmental Protection Agency do not specify beyond what point a fossil fuel power plant's $\mathrm{CO}_{2}$ emission rate should be classified as high, but they do suggest that to screen out especially harmful plants, it is useful to compare a plant's emissions rate to the average for all fossil-fueled plants (U.S. Environmental Protection Agency 1993). In keeping with this recommendation, therefore, we convert our dependent variable to a fuzzy score using the following algorithm recommended by Ragin (2000) for mean-based factors:

$$
\begin{aligned}
& \text { fuzzy score }=\exp \left(2 *{ }^{*} \text { _score }\right) /\left(1+\exp \left(2 * z \_s c o r e\right)\right) \\
& \text { where } z \_s c o r e=(\text { raw_score }- \text { mean }) /(\text { standard deviation })
\end{aligned}
$$

According to this formula, cases with scores closer to 0 are more out of a set, whereas cases with scores closer to 1 are more in a set. In calibrating our key independent variables, we use the same formula if no theory- or knowledge-based information exists about their membership properties. Appendix A in the online supplement reports that of the hypothetically possible configurations $\left(2^{5}=32\right)$, all 32 were empirically observed, the most prominent of which (see column "Freq.") were plants that are in the core, located in nations that are normatively engaged, have political checks and balances, are not owned by dominant utilities, and are old $(\mathrm{CNPdA}=2,969$; cases were determined to belong to a particular configuration using a best-fit measure.) Appendix A in the online supplement also assesses the relationship between the key independent variable sets. Specifically, following the procedures recommended by Longest and Vaisey (2008), it determines which configurations have consistencies with a high $\mathrm{CO}_{2}$ emission rate (Y-Consistency) significantly greater than $0.800^{22}$ (see "Y-Consistency vs. Set Value [0.800]) and significantly greater consistencies with a high $\mathrm{CO}_{2}$ emission rate (Y-Consistency) 
than its negation (N-Consistency) (see "YCons"). ${ }^{23}$ Based on these tests, the most consistent configurations with high $\mathrm{CO}_{2}$ emission rates (see configurations marked as " $Y$ " under "Common Sets") are as follows: (1) plants in core nations that are normatively disengaged, have few political checks and balances, are not owned by dominant utilities, and are not old (Cnpda); (2) plants in core nations that are normatively disengaged, have few political checks and balances, are owned by dominant utilities, and are not old (CnpDa); (3) plants in core nations that are normatively disengaged, have political checks and balances, are owned by dominant utilities, and are not old (CnPDa); (4) plants in core nations that are normatively disengaged, have few political checks and balances, are not owned by dominant utilities, and are old (CnpdA); (5) plants in core nations that are normatively disengaged, have political checks and balances, are not owned by dominant utilities, and are old ( $\mathrm{CnPdA})$; (6) plants in noncore nations that are normatively disengaged, have few political checks and balances, are owned by dominant utilities, and are old (cnpDA); (7) plants in noncore nations that are normatively engaged, have few political checks and balances, are owned by dominant utilities, and are old (cNpDA); (8) plants in core nations that are normatively disengaged, have few political checks and balances, are owned by dominant utilities, and are old (CnpDA); (9) plants in core nations that are normatively disengaged, have political checks and balances, are owned by dominant utilities, and are old (CnPDA); (10) plants in core nations that are normatively engaged, have few political checks and balances, are owned by dominant utilities, and are old (CNpDA); and (11) plants in core nations that are normatively engaged, have political checks and balances, are owned by dominant utilities, and are old (CNDPA).

Because these configurations may logically overlap, they were reduced, ${ }^{24}$ and it was determined that the eleven initial configurations can be collapsed into five. This "Minimum Configuration Reduction Set" turned out to be the final reduction set, which we will discuss in the Results section below.

\section{Multilevel Regression}

Our data structure is such that power plants are cross-nested within countries and power companies. We account for this nesting when conducting our regression analysis of power plants' $\mathrm{CO}_{2}$ emissions for 2009 by using a hierarchical linear model with two random intercepts (one for countries, the other for power companies) (Rabe-Hesketh and Skrondal 2008). Our model also incorporates an unbalanced design that accounts for the fact that there are not the same numbers of plants in each company. We assess model fit (accounting for the number of estimated parameters) using Bayesian information criterion (BIC) statistics that are available in Stata.

Whereas in the past fsQCA was viewed as a standalone alternative to regression analysis, today it is increasingly integrated with regression in mixed-methods approaches, especially when analyzing large samples like ours (Greckhamer et al. 2013). One common strategy is to use fsQCA to assess complex interaction effects and then employ regression to test the robustness of the causally relevant configurations identified by fsQCA (e.g., Grant et al. 2010; Roscigno and Hodson 2004). 
Table 6: Final configurations and coverage statistics of fsQCA analysis.

\begin{tabular}{lccc}
\hline Set & Raw Coverage & Unique Coverage & Solution Consistency \\
\hline $\mathrm{Cnp}^{\mathrm{a}}$ & 0.525 & 0.050 & 0.880 \\
$\mathrm{CnD}$ & 0.469 & 0.010 & 0.960 \\
$\mathrm{CnA}$ & 0.453 & 0.026 & 0.885 \\
$\mathrm{pDA}^{\mathrm{a}}$ & 0.439 & 0.048 & 0.951 \\
$\mathrm{CDA}^{\mathrm{a}}$ & 0.466 & 0.038 & 0.925 \\
\hline
\end{tabular}

Total coverage $=0.739$; solution consistency $=0.830 . \mathrm{C}=$ core; $\mathrm{N}=$ normative engagement; $\mathrm{P}=$ political checks and balances; $\mathrm{D}=$ dominant utility; $\mathrm{A}=$ plant age.

a These configurations were predicted.

This can be done, according to Ragin (see Mendel 2011:9) and Fiss, Sharapov, and Cronqvist (2013:194), by entering configurations' membership scores as predictors into a regression equation that includes controls.

Accordingly, we use this strategy to test our second and third hypotheses. To assess the hypothesis that there is no single structural pathway to emission rates, we conduct an fsQCA analysis to determine whether plants' global, political, and organizational characteristics combine to create the four distinct pathways we predicted. (In other preliminary analyses not reported, we found that each of our key independent variables exerted significant, independent effects.) We also check these configurations' robustness by including the solution membership of each as a predictor ${ }^{25}$ in our regression models containing controls, along with an interaction term for all of the conditions included in the configurations. The latter, according to Ragin (see Mendel 2011:9), ensures that cases that are doubly determined (from a logical point of view) are not doubly counted in a regression analysis. ${ }^{26}$ For the sake of parsimony, we do not present the interaction in the regression tables. And to assess the hypothesis that the four pathways increase emission levels, we reestimate our models using emission levels as the dependent variable.

\section{Results}

\section{fsQCA}

In Table 6, we use fsQCA to test our first hypothesis that global, political, and organizational factors combine to create multiple pathways to power plants' emission rates. The table reports the final reduction set, and in keeping with our expectations, it reveals there are multiple (five) configurations that produce high carbon intensities. Of the five configurations shown here, four match our earlier descriptions of coercive, quiescent, expropriative, and inertial pathways.

When interpreting fsQCA results, it is important to bear in mind that no single attribute within a configuration can be interpreted outside the context of the other attributes. This is because unlike regression techniques that abstract variables from the cases in which they exist, fsQCA treats individual cases as combinations of attributes. Plants defined by the first configuration are in core countries that 
Table 7: Regression analysis of the effects of configurations on power plants' $\mathrm{CO}_{2}$ emission rates (2009).

\begin{tabular}{|c|c|c|c|}
\hline & (1) & (2) & (3) \\
\hline Primarily Coal & $\begin{array}{c}0.451^{\dagger} \\
(0.016)\end{array}$ & $\begin{array}{r}0.449^{\dagger} \\
(0.016)\end{array}$ & $\begin{array}{c}0.114^{\dagger} \\
(0.013)\end{array}$ \\
\hline Primarily Gas & $\begin{array}{r}-0.147^{\dagger} \\
(0.011)\end{array}$ & $\begin{array}{r}-0.143^{\dagger} \\
(0.011)\end{array}$ & $\begin{array}{r}-0.117^{\dagger} \\
(0.009)\end{array}$ \\
\hline Electrical Capacity & $\begin{array}{r}-0.031^{\dagger} \\
(0.002)\end{array}$ & $\begin{array}{r}-0.039^{\dagger} \\
(0.002)\end{array}$ & $\begin{array}{r}-0.018^{\dagger} \\
(0.002)\end{array}$ \\
\hline Private Ownership & $\begin{array}{r}-0.060^{\dagger} \\
(0.015)\end{array}$ & $\begin{array}{c}0.009 \\
(0.016)\end{array}$ & $\begin{array}{c}0.005 \\
(0.013)\end{array}$ \\
\hline Population Size & $\begin{array}{c}-0.003 \\
(0.013)\end{array}$ & $\begin{array}{r}-0.056^{\dagger} \\
(0.017)\end{array}$ & $\begin{array}{c}-0.014 \\
(0.012)\end{array}$ \\
\hline Wealth & $\begin{array}{r}-0.041^{\dagger} \\
(0.014)\end{array}$ & $\begin{array}{r}-0.065^{\dagger} \\
(0.014)\end{array}$ & $\begin{array}{c}-0.009 \\
(0.009)\end{array}$ \\
\hline Price of Electricity & $\begin{array}{c}-0.066 \\
(0.050)\end{array}$ & $\begin{array}{c}-0.038 \\
(0.045)\end{array}$ & $\begin{array}{c}-0.037 \\
(0.030)\end{array}$ \\
\hline Carbon Tax & $\begin{array}{r}-0.332^{\dagger} \\
(0.147)\end{array}$ & $\begin{array}{c}-0.192 \\
(0.155)\end{array}$ & $\begin{array}{c}-0.010 \\
(0.081)\end{array}$ \\
\hline Exports & $\begin{array}{c}0.059 \\
(0.041)\end{array}$ & $\begin{array}{c}0.001 \\
(0.043)\end{array}$ & $\begin{array}{c}-0.006 \\
(0.029)\end{array}$ \\
\hline Foreign Direct Investment & $\begin{array}{c}0.001 \\
(0.020)\end{array}$ & $\begin{array}{c}-0.017 \\
(0.019)\end{array}$ & $\begin{array}{c}-0.003 \\
(0.013)\end{array}$ \\
\hline Plants in Normatively Disengaged Core Countries with & & $0.338^{+}$ & $0.143^{*}$ \\
\hline Few Political Checks and Balances (Cnp) & & $(0.120)$ & $(0.071)$ \\
\hline Plants of Dominant Utilities in Normatively Disengaged & & $0.748^{\dagger}$ & $0.409^{\dagger}$ \\
\hline Core Countries (CnD) & & $(0.081)$ & $(0.059)$ \\
\hline Old Plants in Normatively Disengaged Core Countries (CnA) & & $\begin{array}{c}-0.168 \\
(0.136)\end{array}$ & $\begin{array}{c}-0.132 \\
(0.129)\end{array}$ \\
\hline Old Plants of Dominant Utilities in Countries with & & $0.147^{+}$ & $0.231^{\dagger}$ \\
\hline Few Political Checks and Balances (pDA) & & $(0.051)$ & $(0.042)$ \\
\hline Old Plants of Dominant Utilities in Core Countries (CDA) & & $\begin{array}{r}0.399^{\dagger} \\
(0.062)\end{array}$ & $\begin{array}{r}0.143^{\dagger} \\
(0.051)\end{array}$ \\
\hline Prior $\mathrm{CO}_{2}$ Emission Rate & & & $\begin{array}{r}0.634^{+} \\
(0.005)\end{array}$ \\
\hline Constant & $6.715^{\dagger}$ & $7.907^{\dagger}$ & $2.641^{\dagger}$ \\
\hline $\begin{array}{l}\text { Random Effects of Countries } \\
(N=148 ; \bar{x} \text { Observations per Group }=122)\end{array}$ & $0.033^{\dagger}$ & $0.022^{\dagger}$ & $0.009^{\dagger}$ \\
\hline $\begin{array}{l}\text { Random Effects of Companies } \\
(N=7,583 ; \bar{x} \text { Observations per Group }=2.5)\end{array}$ & $0.139^{\dagger}$ & $0.128^{\dagger}$ & $0.047^{\dagger}$ \\
\hline Residual Variance & $0.201^{\dagger}$ & $0.202^{\dagger}$ & $0.109^{\dagger}$ \\
\hline BIC & 31,165 & 29,991 & 13,808 \\
\hline$N$ & 19,525 & 19,525 & 19,525 \\
\hline
\end{tabular}

${ }^{*} p<0.05 ;{ }^{\dagger} p<0.01$ (two-tailed test). 
are normatively disengaged and have few political checks and balances (coercive configuration). Plants defined by the second configuration are facilities owned by dominant utilities in core countries that are normatively disengaged (quiescent configuration). Plants defined by the third configuration are older facilities in core countries that are civically disengaged. Plants defined by the fourth configuration are older facilities owned by dominant utilities in countries with few political checks and balances (expropriative configuration). And plants defined by the fifth configuration are older facilities owned by dominant facilities in core countries (inertial configuration).

The raw and unique coverage scores indicate, respectively, which share of the outcome is explained by a certain alternative path and which share of the outcome is exclusively explained by a certain alternative path. Table 6 reveals that each pathway or configuration explains between 43.9 percent and 52.5 percent of high $\mathrm{CO}_{2}$ emission rates and 1 to 5 percent of this outcome exclusively. These configurations' solution consistency scores (0.880 to 0.960$)$ suggest that they are very near to being sufficient to produce a high rate of $\mathrm{CO}_{2}$ emissions. Finally, the coverage and consistency scores for the five configurations combined (0.739 and 0.830 ) suggest the total solution explains a large number of cases and often leads to high emission rates.

\section{Regression}

To assess the robustness of the configurations, we conduct regression analyses with various controls in Table 7 . With respect to the controls, findings for model 1 show that plants tend to emit carbon dioxide at significantly higher rates when they rely primarily on coal, emit carbon dioxide at lower rates when they rely primarily on gas, have more electrical capacity that allows for economies of scale, are private or independently owned, are located in wealthier countries, ${ }^{27}$ and have a carbon tax present. In model 2, we test the effects of the configurations identified in the previous fsQCA analysis net of these controls. Here we see that the one configuration for which we did not develop a theoretically motivated configuration-old plants in normatively disengaged core countries-fails to exert a significant effect on emission rates beyond those of the controls. However, each of the other four that we did predict does have a significant, positive effect on plants' carbon intensities. The BIC statistics ${ }^{28}$ indicate that the inclusion of the configurations provides a better model fit than a specification with just the controls. As a final robustness check, we include previous emission rates as a control in model 3 and find that each of the significant effects of the four configurations still holds. Hence, the results of the regression analysis strongly support our second hypothesis that configurations of coercion, quiescence, expropriation, and inertia all significantly increase plants' emission rates net of other predictors.

In Table 8, we test our third hypothesis that these four configurations also exert a significant positive effect on the absolute amount of carbon dioxide that plants emit. Here we replicate our regression analysis but this time substitute plants' emission levels as the dependent variable. A comparison of the model 1 and model 2 BIC statistics reveals again that the addition of the configurations provides a better 
Table 8: Regression analysis of the effects of configurations on power plants' $\mathrm{CO}_{2}$ emission levels (2009).

\begin{tabular}{|c|c|c|c|}
\hline & (1) & (2) & (3) \\
\hline Primarily Coal & $\begin{array}{c}0.675^{\dagger} \\
(0.016)\end{array}$ & $\begin{array}{c}0.672^{\dagger} \\
(0.017)\end{array}$ & $\begin{array}{c}0.444^{\dagger} \\
(0.017)\end{array}$ \\
\hline Primarily Gas & $\begin{array}{r}-0.034^{\dagger} \\
(0.011)\end{array}$ & $\begin{array}{r}-0.037^{\dagger} \\
(0.011)\end{array}$ & $\begin{array}{r}-0.063^{\dagger} \\
(0.011)\end{array}$ \\
\hline Electrical Capacity & $\begin{array}{r}0.967^{\dagger} \\
(0.002)\end{array}$ & $\begin{array}{c}0.963^{\dagger} \\
(0.002)\end{array}$ & $\begin{array}{r}0.744^{+} \\
(0.004)\end{array}$ \\
\hline Capacity Utilization Rate & $\begin{array}{r}0.868^{\dagger} \\
(0.003)\end{array}$ & $\begin{array}{c}0.871^{\dagger} \\
(0.004)\end{array}$ & $\begin{array}{r}0.707^{\dagger} \\
(0.004)\end{array}$ \\
\hline Private Ownership & $\begin{array}{r}-0.042^{\dagger} \\
(0.014)\end{array}$ & $\begin{array}{c}0.003 \\
(0.015)\end{array}$ & $\begin{array}{c}-0.019 \\
(0.016)\end{array}$ \\
\hline Population Size & $\begin{array}{c}-0.007 \\
(0.015)\end{array}$ & $\begin{array}{r}-0.058^{\dagger} \\
(0.020)\end{array}$ & $\begin{array}{r}-0.060^{+} \\
(0.018)\end{array}$ \\
\hline Wealth & $\begin{array}{r}-0.042^{*} \\
(0.018)\end{array}$ & $\begin{array}{r}-0.065^{\dagger} \\
(0.016)\end{array}$ & $\begin{array}{r}-0.062^{\dagger} \\
(0.015)\end{array}$ \\
\hline Price of Electricity & $\begin{array}{c}-0.071 \\
(0.060)\end{array}$ & $\begin{array}{c}-0.040 \\
(0.053)\end{array}$ & $\begin{array}{c}-0.011 \\
(0.032)\end{array}$ \\
\hline Carbon Tax & $\begin{array}{r}-0.391^{*} \\
(0.188)\end{array}$ & $\begin{array}{c}-0.261 \\
(0.157)\end{array}$ & $\begin{array}{c}-0.262 \\
(0.136)\end{array}$ \\
\hline Exports & $\begin{array}{c}0.047 \\
(0.049)\end{array}$ & $\begin{array}{c}0.009 \\
(0.052)\end{array}$ & $\begin{array}{c}-0.028 \\
(0.046)\end{array}$ \\
\hline Foreign Direct Investment & $\begin{array}{c}0.009 \\
(0.023)\end{array}$ & $\begin{array}{c}-0.012 \\
(0.022)\end{array}$ & $\begin{array}{c}-0.028 \\
(0.020)\end{array}$ \\
\hline Plants in Normatively Disengaged Core Countries with & & $0.339^{\dagger}$ & $0.286^{\dagger}$ \\
\hline Few Political Checks and Balances (Cnp) & & $(0.120)$ & $(0.107)$ \\
\hline Plants of Dominant Utilities in Normatively Disengaged & & $0.398^{\dagger}$ & $0.462^{\dagger}$ \\
\hline Core Countries (CnD) & & $(0.080)$ & $(0.073)$ \\
\hline Old Plants in Normatively Disengaged Core Countries (CnA) & & $\begin{array}{c}-0.114 \\
(0.135)\end{array}$ & $\begin{array}{c}-0.247 \\
(0.235)\end{array}$ \\
\hline Old Plants of Dominant Utilities in Countries with & & $0.099^{*}$ & $0.066^{*}$ \\
\hline Few Political Checks and Balances (pDA) & & $(0.048)$ & $(0.032)$ \\
\hline Old Plants of Dominant Utilities in Core Countries (CDA) & & $\begin{array}{c}0.326^{\dagger} \\
(0.060)\end{array}$ & $\begin{array}{r}0.291^{\dagger} \\
(0.062)\end{array}$ \\
\hline Prior $\mathrm{CO}_{2}$ Emission Level & & & $\begin{array}{c}0.234^{+} \\
(0.004)\end{array}$ \\
\hline Constant & $8.739^{\dagger}$ & $9.874^{\dagger}$ & $8.181^{+}$ \\
\hline $\begin{array}{l}\text { Random Effects of Countries } \\
(N=148 ; \bar{x} \text { Observations per Group }=122) \\
\text { Random Effects of Companies }\end{array}$ & $0.058^{\dagger}$ & $0.037^{\dagger}$ & $0.028^{+}$ \\
\hline$(N=7,583 ; \bar{x}$ Observations per Group $=2.5)$ & $0.130^{\dagger}$ & $0.123^{\dagger}$ & $0.062^{\dagger}$ \\
\hline Residual Variance & $0.201^{+}$ & $0.202^{+}$ & $0.170^{+}$ \\
\hline $\mathrm{BIC}$ & 29,736 & 28,693 & 19,425 \\
\hline$N$ & 19,525 & 19,525 & 19,525 \\
\hline
\end{tabular}


model fit. More importantly, although this outcome measure and the previous one are only weakly correlated (0.184), each of the four significant configurations exerts a significant net effect on emissions levels and continues to do so after another control for previous emission levels is added to the model. Hence, the results support our third hypothesis that coercive, quiescent, expropriative, and inertial configurations not only increase power plants' emission rates but also their emission levels.

\section{Discussion}

Our results point to several ways research on carbon pollution might be advanced. First, configurational analyses like the one conducted here can be used to develop more nuanced theoretical arguments. Conventional explanations assert that particular structures like international trade regimes cause pollution and accord them a position of conceptual and causal priority. As a result, theorization about the different ways global, political, and organizational factors might interact to produce carbon pollution is underdeveloped. In contrast, our configurational framework shifts attention to how factors can jointly influence pollution outcomes and thus sets the conceptual groundwork for inquiries into the synergistic determinants of carbon emissions. It assumes there are multiple pathways to an outcome, each consisting of combinations of predictors. Changing any one predictor therefore will not necessarily affect the outcome because there are other pathways.

One can also construct an empirical typology from the analysis above. The findings suggest there are four distinct hyperpolluters: Plants in Normatively Disengaged Core Countries with Few Political Checks and Balances, Plants of Dominant Utilities in Normatively Disengaged Core Countries, Old Plants of Dominant Utilities in Countries with Few Political Checks and Balances, and Old Plants of Dominant Utilities in Core Countries. Researchers can use this typology to select the most causally relevant plants for more in-depth case studies and to determine whether the mechanisms we have suggested explain their effects-coercive, quiescent, expropriative, and inertial-are accurate or need to be refined.

One could also examine configurations within and across countries. For example, Appendix B in the online supplement shows how individual countries score on the four configurations and polluter profiles highlighted here, and Table 9 condenses these data further by reporting which countries have at least one plant that is more in than out of $(>0.65)$ a particular configuration/profile or where a concrete, real-world example of a specific type of hyperpolluter can be found. Using this information, one might compare the experiences of the two types of hyperpolluters found in China, which have what we call expropriative and inertial profiles, to get a better sense of how these mechanisms drive emissions in the world's most heavily polluting country. One might contrast the experiences of inertial plants found in traditional core countries (e.g., United States, United Kingdom) with those that, according to the Clark and Beckfield's (2009) scheme, have recently entered that zone, including several Asian nations (China, India, Indonesia, Malaysia, Pakistan, Singapore, South Korea, and Thailand),"depoliticized" countries of Eastern Europe (Bulgaria, Czech Republic, Hungary, Poland, Romania, and Russia), nations from 
the Middle East (Egypt, Iran, Morocco, Saudi Arabia, Turkey), and countries with large economies in Latin America (Brazil and Mexico). One might also investigate why particular nations (India, Indonesia, Iran, Pakistan, Saudi Arabia, Singapore, and the United Arab Emirates) have all four types of hyperpolluters.

\section{Conclusion}

This study advances research on carbon pollution by examining the synergistic effects of global, political, and organizational factors on power plants' $\mathrm{CO}_{2}$ emissions. Using a unique, worldwide data set assembled by the Center for Global Development, we found that none of these factors, by themselves, is sufficient to explain plants' environmental behavior. Instead, plants' emissions rates are best explained by distinct combinations of these factors, four of which continue to exert significant effects after controlling for other predictors and have similar effects on plants' emission levels as well.

The recognition that climate change and other environmental changes pose a threat to the sustainability of human society has given rise to a variety of sociological perspectives on environmental impacts (Dunlap and Brulle 2015; Nagel, Broadbent, and Dietz 2010), but scholars have struggled to assimilate their ideas. One integrative approach represented by York et al. (2003) is to test perspectives empirically in a common framework so as to determine which of their predictors has the strongest relative impact on aggregate pollution outcomes. An alternative approach, which we are advocating, explores predictors' synergistic effects. This approach is more in keeping with the conclusions of the United Nations and others (International Energy Agency 2009; United Nations Framework Convention on Climate Change 2007) that focus on reducing the emissions of specific sectors or individual polluters as a more manageable strategy than targeting those of entire countries. ${ }^{29}$ And consistent with the notion that climate change is a "wicked problem" that often blends into other issues, our approach investigates the complex ways the causes of carbon pollution may interact.

This study also makes a number of contributions to research on the determinants of organizations' environmental performance. We advance research on the effects of external factors by examining how global economic and normative structures have differential effects on individual organizations within nations, an assumption often implied but rarely examined empirically. More specifically, we extend worldsystems scholarship on the consequences of the core-periphery hierarchy for crossnational differences in carbon pollution and other environmental outcomes by examining the implications of this hierarchy for the environmental behavior of smaller social units (facilities) nested within it (Chase-Dunn and Grimes 1995). And we further world society research on how nations' commitments to global expectations and their actual environmental practices are sometimes decoupled by shifting attention to the sites where decoupling most likely occurs-power plants (Hironaka 2014; see also Rudel 2009).

In demonstrating that organizations' environmental performance is also conditioned by such external factors as national political institutions, we buttress the argument of other researchers that the state is a key strategic action field in which 
Table 9: Configurations and polluter profiles by country.

\begin{tabular}{|c|c|c|c|}
\hline Coercive & Quiescent & Expropriative & Inertial \\
\hline India & Egypt & Afghanistan & Australia \\
\hline Indonesia & India & Angola & Austria \\
\hline Iran & Iran & Azerbaijan & Belgium \\
\hline Pakistan & New Zealand & Bahrain & Brazil \\
\hline Saudi Arabia & Pakistan & Bangladesh & Bulgaria \\
\hline Singapore & Saudi Arabia & Belarus & Canada \\
\hline \multirow[t]{44}{*}{ United Arab Emirates } & South Korea & Cambodia & China \\
\hline & Singapore & Central African Republic & Czech Republic \\
\hline & Thailand & China & Denmark \\
\hline & United States & Cuba & Egypt \\
\hline & United Arab Emirates & Cameroon & Finland \\
\hline & & Comoros & France \\
\hline & & Ecuador & Germany \\
\hline & & El Salvador & Greece \\
\hline & & Fiji & Hungary \\
\hline & & Guinea & India \\
\hline & & Haiti & Indonesia \\
\hline & & Honduras & Iran \\
\hline & & India & Ireland \\
\hline & & Indonesia & Italy \\
\hline & & Iran & Japan \\
\hline & & Iraq & Malaysia \\
\hline & & Jordan & Mexico \\
\hline & & Kuwait & Morocco \\
\hline & & Laos & Norway \\
\hline & & Liberia & Pakistan \\
\hline & & Libya & Poland \\
\hline & & Madagascar & Portugal \\
\hline & & Mexico & Romania \\
\hline & & Nicaragua & Russia \\
\hline & & North Korea & Saudi Arabia \\
\hline & & Pakistan & Singapore \\
\hline & & Peru & Spain \\
\hline & & Qatar & Sweden \\
\hline & & Rwanda & Switzerland \\
\hline & & Saudi Arabia & Thailand \\
\hline & & Senegal & Turkey \\
\hline & & Singapore & Ukraine \\
\hline & & Slovenia & United Arab Emirates \\
\hline & & Solomon Islands & United Kingdom \\
\hline & & Spain & United States \\
\hline & & Sri Lanka & \\
\hline & & Sudan & \\
\hline & & Taiwan & \\
\hline & & Tunisia & \\
\hline & & Turkmenistan & \\
\hline & & United Arab Emirates & \\
\hline & & Vietnam & \\
\hline & & Yemen & \\
\hline & & Zambia & \\
\hline
\end{tabular}

A country is reported to have at least one power plant with a particular configuration or profile if its maximum value on that profile or configuration is $>0.65$. Because individual plants can have values that exceed this threshold for more than one of these sets, their countries may also be classified as belonging to more than one of the categories listed above. 
the rules for legitimate collective action are defined and enforced (Fligstein and McAdam 2015). By the same token, we go beyond this research in advancing a strategy for studying the possible interactions between incumbents who yield disproportionate influence (e.g., members of the fossil fuel industry), challengers who occupy less privileged positions (e.g., EINGOs), and governance units that more or less concentrate political power and determining which are the most causally relevant to an outcome within a particular domain. Thus, our approach is consistent with those who warn against making any one actor the central animating force in a field (McAdam and Boudet 2012).

In showing that carbon pollution is shaped by the larger economic, normative, and political environments in which power plants operate, we thus bolster the claim of open systems scholars (Scott 1992) that an organization's behavior is conditioned by its external properties. At the same time, we have improved on open system accounts by directing attention to those organizational actors that do the most harm. Organizational scholars have been slow to study how and why particular kinds of power plants emit more carbon pollution than most, even though the issue of climate change will likely shape the relevance of future organizational studies (Perrow 2010; Perrow and Pulver 2015). Our configurational approach can also be extended to future studies of other types of organizations that may have disproportionate impacts on specific outcomes depending on their structures, such as universities and inequality.

And we have improved on open system accounts by showing how one might analyze the interplay between external features of organizations. When organizational scholars studied the effects of external features in the past, they typically tried to statistically isolate the effects of those features of organizations. Or on the occasions when they have examined how external features interact, they stop short of determining which of the theoretically possible interactions are the most causally relevant. And despite the fact that some endorse the concept of equifinality-the idea that there are different causal pathways to the same outcome-they rely solely on standard regression techniques that estimate a single path for all cases under examination.

In contrast, our configurational approach treats organizations holistically in the sense that each individual case is considered a complex entity. It also assumes that the attributes that causally define organizations fall into coherent patterns, and therefore it employs a case-based methodology (fsQCA) that can identify which of the possible combinations of attributes are needed to explain a large fraction of outcomes. Here we found, for instance, that of 32 theoretically possible configurations, four can explain nearly every instance of a power plant emitting carbon dioxide at a high rate.

Having suggested the strengths of our approach, it is important to acknowledge its limitations. First, theorization about and empirical analyses of the synergistic sources of carbon pollution are still in their infancy. Therefore, in trying to make the case for a configurational model, we had few configurational predictions to build upon and were forced to develop hypotheses partly from scratch. We also realize that some may view the computer and programming techniques used here to generate configurations as a crude form of systematic empiricism. Nonetheless, 
we believe that with more rough-cut slabs of findings like those presented here, the empirical foundations of an original, configurational theory of carbon pollution can be slowly erected. And as others become more familiar with fsQCA techniques, they will appreciate how they can provide the analytical legs such a theory needs to run on.

Second, if this line of configurational research is to be fruitful, additional theorization is needed to explain what generates configurations. We have suggested that processes having to do with coercion, quiescence, expropriation, and inertia may explain the observed effects of configuration. However, several exogenous and endogenous forces seem capable of causing global, political, and organizational factors to cluster systematically but have not been explored here. These range from environmental selection processes (Hannan and Freeman 1989) and the diffusion of mimetic and normative strategies (DiMaggio and Powell 1983) to functional relationships among structures (Miller 1987) and the replication of time-honored practices (Berger and Luckman 1967). In addition to determining which of these forces help create clusters, scholars should investigate the stability of clusters over time, which would shed new light on the emergence and survival of particular organizational forms.

Third, as suggested above, additional research is needed to explain the effects of particular factors. As more nuanced worldwide data become available on power plants' ownership status and other corporate structures, researchers should determine if the effect of dominant utilities depends on whether, for example, they are owned by the state or investors. Likewise, it will be important to elaborate on the effects of nations' political institutions to find out, for example, how differences in national climate change policies, market orientations, military investments, lobbying activities, entrepreneurship, and income inequality affect emission outcomes (Pulver 2011; Rosa and Dietz 2012). To better understand the effects of environmental norms, researchers should also examine the ability of EINGOs to construct collective action frames through the national media to delegitimize organizations that exploit natural resources (McLaughlin 2011; Farrell 2016; see also Shriver, Adams, and Cable2013;). Although collecting information on frames that target specific organizations can be time and cost prohibitive, with the advent of big data, such tasks are now increasingly doable and could provide valuable insights into the impact of socially constructed landscapes on organizations' environmental behavior.

Fourth, although our study sheds light on the profiles of hyperpolluting power plants, it says nothing about those of green stars. Additional research is needed on these organizations in the electricity sector and other segments of the economy that have taken a low-carbon pathway. Using the configurational framework and strategy advocated here, scholars can begin to determine which constellations of global, political, and organizational properties distinguish these environmental leaders.

Fifth, research on hyperpolluting power plants needs to be extended beyond the period examined here when not only the effects of climate change are increasingly felt but nationalist movements have also grown. The unfolding environmental crisis in North and Southeast Asia has reinforced that region's predisposition toward 
top-down solutions. At the same time, more leaders of authoritarian populist movements in the European Union and United States have been elected into public office, threatening to unmoor those countries' checks and balances and, in the case of the United States, withdrawing from global climate change agreements. A key question for future studies, therefore, is what are the impacts of different forms of centralized decision-making on the emission rates and emission levels of hyperpolluters?

In short, we are fully aware that our study is but a beginning; many other structures and connections between them will need to be investigated to complete our understanding of the climatic damage caused by the world's power plants.

\section{Notes}

1 In this study, structure is understood as the relatively durable features of organizations and the larger systems and institutions in which they operate that enhance or constrain their access to resources and define the rules governing legitimate action.

2 In this study, interaction is understood in two senses. The first, which is the more conventional one, is associated with quantitative, variable-based approaches like regression. It is premised on assumptions about sampling and the distribution of data and refers to the extent to which the average effect of two factors together exceeds the average effect of each factor considered individually. The second is associated with qualitative, case-oriented approaches like QCA and fsQCA. It is based on an examination of sets, subsets, and supersets of cases and refers to the combinations of conditions that are necessary and sufficient to produce an outcome. We use the latter approach to identify the sets of global, political, and organizational conditions associated with power plants' high $\mathrm{CO} 2$ emission rates.

3 Just as there are debates about which social structures are the best predictors of carbon pollution, there are longstanding disagreements about whether emission rate or level is the most appropriate measure of carbon pollution (Ellerman and Wing 2003). Rather than take sides on this issue, and consistent with other sociological research on carbon emissions (e.g., Jorgenson and Clark 2012; Longhofer and Jorgenson 2017), we take a middle approach and examine which combinations of global, political, and organizational factors best explain plants' emission rates (the most widely used measure in the regulation of greenhouse gases) and then test whether those same combinations significantly increase plants' emission levels.

4 Although our study does not address how and why new power plants are created, it nonetheless examines the performance of existing ones, which are a key component of regulatory strategies that target electricity sectors. Also, data on the carbon emissions that result from the construction of new plants are unavailable.

5 For similar arguments within environmental sociology, see the metabolic rift and treadmill of production frameworks that suggest there is an incompatibility and "enduring conflict" between economic production and ecological limits (Foster, Clark, and York 2010; Gould, Pellow, and Schnaiberg 2008).

6 For similar arguments within environmental sociology, see the ecological modernization perspective (Mol, Spaargaren, and Sonnenfeld 2014), which argues, contrary to treadmill of production and metabolic rift researchers (Foster 1999; Gould et al. 2008), that capitalism is compatible with environmental protection (see also Fisher and Freudenburg 2004). 
7 At the time of this writing, the CARMA data set had not been extended beyond 2009 because its architects want an international agency to take over responsibility for updating their file and thus make it part of a global regulation system. Groups like the World Resources Institute have expressed an interest in collaborating with the United Nations on this task but have not yet produced more up-to-date information. Although CARMA's emission data coincide with the most recent global economic crisis, it is important to note that the worldwide dip in $\mathrm{CO} 2$ emissions during the so-called Great Recession was disproportionally smaller than the increases economies usually experience when they are growing (York 2012). This is because growth produces durable products and infrastructure, such as utilities and electrical grids, which are not removed by economic decline and thus can continue to contribute to $\mathrm{CO} 2$ emissions even after growth is curtailed. This would suggest, therefore, that the time period studied here may not be appreciably different than the years of recovery that followed.

8 The architects of CARMA used accumulative prediction error (APE) techniques to assess the adequacy of their estimated measures of carbon intensity (Wheeler and Ummel 2008; Ummel 2012). They found that across all plants, the reported value for carbon intensity is within 20 percent of the actual value in 85 percent of cases. CARMA's estimates were also superior to those derived from a "naïve" model that assumes each plant's capacity factor (ratio of actual output to potential output) is equal to the average for specific fuel types and a "pseudo-optimal" model that assumes last year's observed plant-specific capacity factor remains the same. Importantly, the reduction in estimation errors using CARMA's modeling procedure works best among the biggest polluters, which are the focus of this study. According to Wheeler and Ummel, this is likely because such facilities operate by more regular and predictable rules. In addition, a comparison of the estimated values and the publicly available data for a sample of almost 3,500 power plants, including approximately 800 plants with publicly available data from outside the United States, indicates that the CARMA estimates quite accurately capture broad differences among plants of various types and sizes (R2 statistics $>0.90$ ). CARMA also compares well with other regularly used data, thus adding to its validity. For example, we summed CARMA's plant-level emissions data for the fossil fuel power plants in each country and compared those values with the International Energy Agency's (IEA) 2009 annual national measures of carbon dioxide emissions from fossil fuel combustion for the electricity production sector. The Pearson's correlation for our summed measure of national $\mathrm{CO} 2$ emissions from fossil fuel power plants and the IEA's measure is 0.93 . We also compared regression results for plants from reporting and nonreporting countries and found the same variables exerted significant effects on emission outcomes in both groups. The results using our full sample were not altered when a dummy variable for nonreporting plants was included in our models. Both sets of tests, therefore, suggested that errors in measurement did little to explain variability in plants' attributes and outcomes.

9 Coordinates can also be used in conjunction with geographic information system technology to map the locations of particular plants.

10 Using multiple indicators of a concept poses a challenge for fsQCA because the number of possible combinations of conditions increases exponentially $(2,000)$ as more conditions are included in the analysis, making the interpretation of configurations with numerous conditions unwieldy. Following the recommendations of Fiss (2011), we addressed this situation using data-reduction techniques. Specifically, we conducted principal component factor analyses of various indicators of world-system position (Table 2), world environmental norms (Table 3), and organizational factors (Table 4). 
11 This measure is derived from a network analysis of international import data that captures how the core sector has expanded to include rapidly developing countries like China and India. Clark and Beckfield (2009) also show that countries between the zones they identify have diverged over time, whereas those within them have converged.

12 We also decided against including a set for core, semiperiphery, and periphery location in our fuzzy-set analyses, all of which are binary, because a plant obviously cannot be in more than one, so any configuration that involves all three would be eliminated from the analysis.

13 Data come from the Union of International Association's Yearbook of International Organizations (Union of International Associations 2009). Published annually, the yearbook provides membership information for more than 37,000 international organizations. Longhofer et al. (2016) generated a list of all EINGOs using the yearbook's subject indices, which were then organized by founding date. Coders then sampled every eighth organization (or roughly 13 percent of the population) and gathered annual membership information for each one. This yielded a final sample of 54 EINGOs. We thank David Frank for sharing these data with us. Data on environmental legislation are also used in Longhofer et al. (2016) and come from ECOLEX (www.ecolex.org). Data on treaties come from the United Nations Environment Programme Environmental Data Explorer (http:/ / geodata.grid.unep.ch/) and were provided by Tricia Bromley.

14 This measure is related to but distinct from indices of democracy. Although democracies tend to favor decentralized decision-making, this is not always the case (for example, where a unicameral parliament is governed by a majoritarian party). Also, unlike our measure of political institutions, we found that traditional indicators of democracy (e.g., Freedom House) did not have significant direct or indirect effects on plants' emissions.

15 Platt's World Electric Power Plants Database does not distinguish between publicly owned and investor-owned utilities. According to its codebook, there are simply too many varieties of utilities today to make a precise determination of what percent of a facility is owned by whom (e.g., many state-owned power companies have been partially privatized, but the original government owner may retain a golden share). Still, as Perrow (2010) suggests, the ownership status of utilities may be less consequential for climate change than their size, which is captured by our scale's other two items.

16 The carbon content of coal also varies by its moisture, but systematic information on the latter is not available for most plants, nor can it be readily estimated.

17 When testing the effects of configurations on plants' emission levels, we also include a control for capacity utilization rate (percent of potential output that was produced). We do not include capacity utilization rate in our models for emission rates because including it and electrical capacity in the same equation essentially confounds the denominator of the dependent variable. Importantly, findings are substantively the same for the configurations if capacity utilization rate is included as a predictor of emission rates.

18 These are companies that either built new power plants or acquired power plants previously under the control of investor-owned utilities or state-owned utilities and then operated the plants in a nominally competitive fashion.

19 Importantly, in controlling for previous emissions, our goal is still to explain emission rates and emission levels as opposed to changes in these outcomes.

20 The effect of a predictor can vary by type of case, as indicated by cases' joint values on multiple other predictors (i.e., statistical moderation). For example, predictors like location in the core of the world-system may differ based on other factors, which include their (combination of) values on other attributes. 
21 Both consistency and coverage are calculated using the same formula ( $\mathrm{m} \min (\mathrm{Xi}, \mathrm{Yi}) /$ $\Sigma Y i)$. However, coverage is only calculated after it has been established that a given pathway $(X)$ is a consistent subset of $Y$ (Ragin 2000).

22 We set the threshold at 0.80 ("almost always sufficient"), as is considered appropriate for samples with a large N (Greckhamer, Misangyi, and Fiss 2013; Ragin 2008).

23 Contradictory configurations occur when cases in the same configuration show different outcomes, which weaken set theoretic consistency and make it more difficult to draw inferences about causal relationships. Stata only reports figures regarding the "Y-Consistency vs. N-Consistency" test for common sets that passed as true (indicated under the column "Common Sets" as "Y").

24 This process, also known as minimization, is done by an automated algorithm that takes two configurations at a time and examines if they have the same outcome. If so, and if their configurations are only different in respect to one condition, this is deemed to not be an important causal factor and the two configurations are collapsed into one. This process of comparisons is continued, looking at all configurations (including newly collapsed ones) until no further reductions are possible.

25 These predictors are actual membership scores as opposed to dummy variables for cases above or below a certain membership level.

26 We did not split the data set and use one fraction for fsQCA and the other for the regression models for two reasons. First, the logic of generalizing from random samples to populations in regression analyses presupposes a substantial degree of homogeneity of cases in the population that may not exist. Second, random sampling is not appropriate for studies like this one that are interested in exploring the diversity of cases. A random sample may not represent the full diversity of cases because some may occur only rarely in a population (Greckhamer et al. 2013).

27 The negative effects of national-level population and wealth on plant-level emissions in some of our models differ from studies of national-level emissions that report these factors have positive effects. This discrepancy may be because these other studies have been conducted at the national level and thus do take into account the characteristics of smaller-scale individual polluters such as power plants.

28 The BIC statistic measures the relative likelihood of the models given the data. Models with more negative BIC scores have a higher relative likelihood.

29 Our findings also lend support to the policy recommendations of some United Nations officials that setting carbon intensity targets is an effective strategy for reducing both emission rates and levels. Research on "rebound effects" has questioned this strategy, suggesting that improvements in emission efficiency will have the adverse effect of increasing output and, in turn, the volume of emissions. However, our findings cast doubt on these criticisms, showing that emission rates and levels are due to similar causes, especially at the level of individual power plants.

\section{References}

Beckfield, Jason. 2003. "Inequality in the World Polity: The Structure of International Organization." American Sociological Review 68:401-24. https ://doi . org/10. 2307/1519730.

Bergara, Mario E., Witold J. Henisz, and Pablo T. Spiller. 1998. "Political Institutions and Electric Utility Investment: A Cross-Nation Analysis." California Management Review 40:18-35. https://doi .org/10.2307/41165931. 
Berger, Peter L., and Thomas Luckman. 1967. The Social Construction of Reality. New York, NY: Doubleday.

Bromley, Patricia, and Walter W. Powell. 2012. "From Smoke and Mirrors to Walking the Talk: Decoupling in the Contemporary World." Academy of Management Annals 6:483-530. https://doi.org/10.1080/19416520.2012.684462.

Bullard, Robert D. 1993. “Anatomy of Environmental Racism and the Environmental Justice Movement." Pp. 15-29 in Confronting Environmental Racism: Voices from the Grassroots. Cambridge MA: South End Press.

Buttel, Frederick H. 2000. "World Society, the Nation-State, and Environmental Protection: Comment on Frank, Hironaka, and Schofer." American Sociological Review 65:117-21. https://doi.org/10.2307/2657292.

Buttel, Frederick H. 2004. "The Treadmill of Production: An Appreciation, Assessment, and Agenda for Research." Organization and Environment 17:323-36. https://doi .org/10. $1177 / 1086026604267938$.

Chase-Dunn, Christopher, and Peter Grimes. 1995. "World-Systems Analysis." Annual Review of Sociology 21:387-417. https : //doi .org/10.1146/annurev . so . 21.080195.002131.

Clark, Rob, and Jason Beckfield. 2009. "A New Trichotomous Measure of World-system Position Using the International Trade Network." International Journal of Comparative Sociology 50:5-38. https://doi .org/10.1177/0020715208098615.

Crilly, Donal 2013. "Corporate Social Responsibility: A Multilevel Explanation of Why Managers Do Good." Research in Sociology of Organizations 58:190-213. https : //doi .org/ 10.1108/S0733-558X (2013)0000038012.

Dietz, Thomas 2015. "Prolegomenon to a Structural Human Ecology of Human Well-being." Sociology of Development 1:123-48. https ://doi.org/10.1525/sod.2015.1.1.123.

Dietz, Thomas, Eugene A. Rosa, and Richard York. 2010. “Human Driving Forces of Global Change: Dominant Perspectives." Pp. 83-134 in Human Footprints on the Global Environment: Threats to Sustainability, edited by E. Rosa, A. Diekmann, T. Dietz, and C. Jaeger. Cambridge, MA: MIT Press.

Dietz, Thomas, Kenneth A. Frank, Cameron T. Whitley, Jennifer Kelly, and Rachel Kelly. 2015. "Political Influences on Greenhouse Gas Emissions from US States." Proceedings of the National Academy of Sciences 112:8254-59. https://doi .org/10.1073/pnas. 1417806112.

DiMaggio, Paul J., and Walter W. Powell. 1983. “The Iron Cage Revisited: Institutional Isomorphism and Collective Rationality in Organizational Fields." American Sociological Review 48:147-60. https: //doi .org/10.2307/2095101.

Dunlap, Riley E., and Robert J. Brulle, eds. 2015. Climate Change and Society: Sociological Perspectives. New York, NY: Oxford University Press. https://doi .org/10.1093/acprof : oso/9780199356102.001.0001.

Ellerman, A. Denny, and Ian Sue Wing. 2003. “Absolute Versus Intensity-Based Emission Caps." Climate Policy 3:7-20. https ://doi.org/10.1016/j .clipol.2003.09.013.

Fisher, Dana R., and William R. Freudenburg. 2004. "Post Industrialization and Environmental Quality: An Empirical Analysis of the Environmental State." Social Forces 83:157-88. https://doi.org/10.1353/sof .2004.0108.

Fiss, Peer C. 2007. "A Set-Theoretic Approach to Organizational Configurations." Academy of Management Review 32:1180-98. https://doi .org/10.5465/AMR . 2007.26586092.

Fiss, Peer C. 2011. “Building Better Causal Theories: A Fuzzy Set Approach to Typologies in Organization Research." Academy of Management Journal 54:393-420. https://doi .org/ 10.5465/AMJ . 2011.60263120. 
Fiss, Peer C., Bart Cambré, and Axel Marx, eds. 2013. Configurational Theory and Methods in Organizational Research. Bingley, UK: Emerald Group Publishing. https ://doi .org/10. 1108/S0733-558X (2013) 38.

Fiss, Peer C., Dmitry Sharapov, and Lasse Cronqvist. 2013. "Opposites Attract? Opportunities and Challenges for Integrating Large-N QCA and Econometric Analysis." Political Research Quarterly 66: 191-8.

Fligstein, Niel, and Doug McAdam. 2015. A Theory of Fields. New York, NY: Oxford University Press.

Foster, John Bellamy. 1999. “Marx's Theory of Metabolic Rift: Classical Foundations for Environmental Sociology." American Journal of Sociology 105:366-405. https : //doi .org/ $10.1086 / 210315$.

Foster, John Bellamy, Brett Clark, and Richard York. 2010. The Ecological Rift: Capitalism's War on the Earth. New York: Monthly Review Press.

Frank, David John, Ann Hironaka, and Evan Schofer. 2000. "The Nation-state and the Natural Environment over the Twentieth Century." American Sociological Review 65:96116. https://doi.org/10.2307/2657291.

Freudenburg, William R. 2005. “Privileged Access, Privileged Accounts: Toward a Socially Structured Theory of Resources and Discourses." Social Forces 84:89-114. https://doi . org/10.1353/sof . 2005.0096.

Gould, Kenneth A., David Naguib Pellow, and Allan Schnaiberg. 2008. The Treadmill of Production: Injustice and Unsustainability in the Global Economy. Boulder, CO: Paradigm Publishers.

Grant, Don, Andrew W. Jones, and Albert J. Bergeson. 2002. “Organizational Size and Pollution: The Case of the U.S. Chemical Industry." American Sociological Review 37:389407.

Grant, Don, Mary Nell Trautner, Liam Downey, and Lisa Thiebaud. 2010. "Bringing the Polluters Back in: Environmental Inequality and the Organization of Chemical Production." American Sociological Review 75:479-504. https://doi .org/10.1177/0003122410374822.

Grant, Don, Andrew Jorgenson, and Wesley Longhofer. 2013. "Targeting Electricity's Extreme Polluters to Reduce Energy-related $\mathrm{CO}_{2}$ Emissions." Journal of Environmental Studies and Sciences 3:376-80.

Greckhamer, Thomas, Vilmos F. Misangyi, and Peer C. Fiss. 2013. "The Two QCAs: From a Small-N to a Large-N Set Theoretic Approach." Research in Sociology of Organizations 58:51-77. https://doi.org/10.1108/S0733-558X(2013)0000038007.

Hannan, Michael T., and John. H. Freeman. 1989. Organizational Ecology. Cambridge, MA: Harvard University Press.

Henisz, Witold J. 2002. “The Institutional Environment for Infrastructure Investment." Industrial and Corporate Change 11:355-89. https://doi .org/10.1093/icc/11.2.355.

Henisz, Witold J. 2009. "Political Constraint Index (Polcon) Dataset." Philadelphia: University of Pennsylvania. Retrieved July 1, 2016. https : / whartonmgmt . wufoo.com/forms/ political-constraint-index-polcon-dataset/.

Henisz, Witold J., Bennet A. Zelner, and Mauro F. Guillén. 2005. “The Worldwide Diffusion of Market-oriented Infrastructure Reform, 1977-1999." American Sociological Review 70:87197. https://doi.org/10.1177/000312240507000601.

Hironaka, Ann. 2014. Greening the Globe: World Society and Environmental Change. New York, NY: Cambridge University Press. https ://doi .org/10.1017/CB09781139381833. 
Intergovernmental Panel on Climate Change. 2014. Climate Change 2014: Synthesis Report. Retrieved July 1, 2017. http://www. ipcc.ch/report/ar5/syr/.

International Energy Agency. 2009. "Energy and Climate Change." Retrieved July 1, 2016. https://www . iea.org/weo/energyandclimatechange/.

Jorgenson, Andrew K., and Brett Clark. 2012. "Are the Economy and the Environment Decoupling? A Comparative International Study, 1960-2005." American Journal of Sociology 118:1-44. https://doi.org/10.1086/665990.

Jorgenson, Andrew K., Christopher Dick, and Matthew C. Mahutga. 2007. "Foreign Investment Dependence and the Environment: An Ecostructural Approach." Social Problems 54:371-94. https://doi.org/10.1525/sp.2007.54.3.371.

Jorgenson, Andrew K., Christopher Dick, and John M. Shandra. 2011. “World Economy, World Society, and Environmental Harms in Less-developed Countries." Sociological Inquiry 81:53-87. https : //doi.org/10.1111/j.1475-682X.2010.00354.x.

Jorgenson, Andrew K., Wesley Longhofer, and Don Grant. 2016. “Disproportionality in Power Plants' Carbon Emissions: A Cross-national Study." Scientific Reports 6:28661. https://doi.org/10.1038/srep28661.

Longest, Kyle, and Stephen Vaisey. 2008. "Fuzzy: A Program for Performing Qualitative Comparative Analyses (QCA) in Stata." Stata Journal 8:79-104.

Longhofer, Wesley, and Andrew Jorgenson. 2017. “Decoupling Reconsidered: Does World Society Integration Influence the Relationship Between the Environment and Economic Development?" Social Science Research 65:17-29. https://doi .org/10.1016/j . ssresearch . 2017.02 .002$.

Longhofer, Wesley, and Evan Schofer. 2010. "National and Global Origins of Environmental Association." American Sociological Review 75:505-33. https://doi.org/10.1177/ 0003122410374084.

Longhofer, Wesley, Evan Schofer, Natasha Miric, and David John Frank. 2016. “NGOs, INGOs, and Social Change: Environmental Policy Reform in the Developing World, 1970-2010." Social Forces 94:1743-68. https : //doi .org/10.1093/sf/sow031.

Marquis, Christopher, Michael W. Toffel, and Yanhua Zhou. 2016. "Scrutiny, Norms, and Selective Disclosure: A Global Study of Greenwashing." Organization Science 27:483-504. https://doi.org/10.1287/orsc.2015.1039.

McAdam, Doug, and Hilary Boudet. 2012. Putting Social Movements in Their Place: Opposition to Energy Projects, 2000-2005. New York: Cambridge University Press. https: //doi .org/ 10.1017/CB09781139105811.

McLaughlin, Paul. 2011. “Climate Change, Adaptation, and Vulnerability: Reconceptualizing Societal-Environment Interaction within a Socially Constructed Adaptive Landscape." Organization and Environment 24:269-91. https://doi .org/10.1177/1086026611419862.

Mendel, Jerry M., and Charles C. Ragin. 2011. "fsQCA: Dialog between Jerry M. Mendel and Charles C. Ragin." USC-SIPI Report \#411.

Miller, Danny. 1987. “The Genesis of Configuration.” Academy of Management Review 12:686701.

Mol, Arthur P. J., Gert Spaargaren, and David A. Sonnenfeld. 2014. “Ecological Modernization Theory: Taking Stock, Moving Forward." Pp. 15-30 in The Routledge International Handbook of Social and Environmental Change, edited by S. Lockie, D. Sonnenfeld, and D. Fisher. New York, NY: Routledge Press.

Nagel, Joane, Jeffrey Broadbent, and Thomas Dietz. 2010. “Workshop on Sociological Perspectives on Climate Change." American Sociological Association/National Science Foundation. 
Perrow, Charles. 2010. "Organizations and Global Warming," Pp. 59-77 in Routledge Handbook of Climate Change and Society, edited by Constance Lever-Tracy. New York, NY: Routledge Press.

Perrow, Charles, and Simone Pulver. 2015. "Organizations and Markets." In Climate Change and Society: Sociological Perspectives, edited by R. Dunlap and R. Brulle. New York, NY: Oxford University Press.

Podobnik, Bruce. 2006. Global Energy Shifts: Fostering Sustainability in a Turbulent Age. Philadelphia, PA: Temple University Press.

Prechel, Harland, and George Touche. 2014. "The Effects of Organizational Characteristics and State Environmental Policies on Sulfur-dioxide Pollution in U.S. Electrical Energy Corporations." Social Science Quarterly 95:76-96. https ://doi .org/10.1111/ssqu . 12052.

Prechel, Harland, and Lu Zheng. 2012. "Corporate Characteristics, Political Embeddedness, and Environmental Pollution by Largest U.S. Corporations." Social Forces 90:947-70. https://doi.org/10.1093/sf/sor026.

Prechel, Harland, and Alesha Istvan. 2016. “Disproportionality of Corporations' Environmental Pollution in the Electrical Energy Industry." Sociological Perspectives 59:505-27. https://doi .org/10.1177/0731121416629991.

Pulver, Simone. 2011. “Corporate Responses." Pp. 581-92 in The Oxford Handbook of Climate Change and Society, edited by J. Dryzek, R. Norgaard, and D. Schlosberg. Oxford, UK: Oxford University Press. https://doi.org/10.1093/oxfordhb/9780199566600.003. 0039.

Rabe-Hesketh, Sophia, and Anders Skrondal. 2008. Multilevel and Longitudinal Modeling Using Stata, 2nd ed. College Station, TX: Stata Press.

Ragin, Charles C. 2000. Fuzzy-set Social Science. Chicago, IL: University of Chicago Press.

Ragin, Charles C., and Peer C. Fiss. 2008. “Net Effects Versus Configurations: An Empirical Demonstration." Pp. 190-212 in Redesigning Social Inquiry: Fuzzy Sets and Beyond, edited by C. C. Ragin. Chicago, IL: Chicago University Press. https://doi.org/10.7208/ chicago/9780226702797.001.0001.

Roberts, J. Timmons, and Peter Grimes. 2002. "World-system Theory and the Environment: Toward a New Synthesis." Pp. 167-96 in Sociological Theory and the Environment: Classical Foundations, Contemporary Insights, edited by R. Dunlap, F. Buttel, P. Dickens, and A. Gijswijt. Lanham, MD: Rowman and Littlefield.

Roberts, J. Timmons, and Bradley C. Parks. 2007. A Climate of Injustice: Global Inequality, North-South Politics, and Climate Policy. Cambridge, MA: MIT Press.

Rosa, Eugene A., and Thomas Dietz. 2012. "Human Drivers of National Greenhouse-gas Emissions." Nature Climate Change 2:581-6. https ://doi .org/10.1038/nclimate1506.

Roscigno, Vincent J., and Randy Hodson. 2004. "The Organizational and Social Foundations of Worker Resistance." American Sociological Review 69:14-39. https://doi.org/10. $1177 / 000312240406900103$.

Rudel, Thomas K. 2009. "How Do People Transform Landscapes? A Sociological Perspective on Suburban Sprawl and Tropical Deforestation." American Journal of Sociology 115:129-54. https://doi.org/10.1086/597794.

S\&P Global Platts. 2009. "World Electric Power Plants Database." Retrieved July 1, 2016. https://www.platts.com/products/world-electric-power-plants-database.

Schofer, Evan, and Ann Hironaka. 2005. "The Effects of World Society on Environmental Protection Outcomes." Social Forces 84:25-47. https://doi.org/10.1353/sof.2005. 0127. 
Schelly, David, and Paul B. Stretesky. 2009. "An Analysis of the 'Path of Least Resistance' Argument in Three Environmental Justice Success Cases." Society and Natural Resources 22:369-80. https://doi.org/10.1080/08941920802119648.

Scott, W. Richard. 1992. Organizations: Rational, Natural and Open Systems. 3rd ed. Englewood Cliffs, NJ: Prentice-Hall.

Shandra, John M., Christopher Leckband, Laura A. McKinney, and Bruce London. 2009. "Ecologically Unequal Exchange, World Polity, and Biodiversity Loss: A Cross-National Analysis of Threatened Mammals." International Journal of Comparative Sociology 50:285310. https://doi.org/10.1177/0020715209105143.

Shorette, Kristen. 2012. “Outcomes of Global Environmentalism: Longitudinal and CrossNational Trends in Chemical Fertilizer and Pesticide Use." Social Forces 91:299-325. https://doi.org/10.1093/sf/sos053.

Shriver, Thomas E., Alison E. Adams, and Chris M. Messer. 2014. "Power, Quiescence, and Pollution: The Suppression of Environmental Grievances." Social Currents 1:275-92. https://doi.org/10.1177/2329496514540133.

Shriver, Thomas E., Alison E. Adams, and Sherry Cable. 2013. "Discursive Obstruction and Elite Opposition to Environmental Activism in the Czech Republic." Social Forces 91:873-93. https://doi.org/10.1093/sf/sos183.

Shwom, Rachael. 2009. "Strengthening Sociological Perspectives on Organizations and the Environment." Organization E Environment 22:271-92. https://doi .org/10.1177/ 1086026609345216.

Shwom, Rachael. 2011. "A Middle Range Theorization of Energy Politics: The Struggle for Energy Efficient Appliances.” Environmental Politics 20:705-26. https://doi.org/10. 1080/09644016.2011.608535.

Union of International Associations. 2009. Yearbook of International Organizations. Brussels: Union of International Associations.

United Nations Framework Convention on Climate Change. 2007. "Bali Action Plan." FCCC/CP/2007/6/Add.1, Conference of the Parties on its Thirteenth Session. Retrieved July 1, 2016. https://unf ccc. int/resource/docs/2007/cop13/eng/06a01.pdf.

U.S. Environmental Protection Agency. 1993. Toxics Release Inventory. Washington, DC: Office of Pollution Prevention and Toxics.

Weber, Max. [1922] 1978. Economy and Society: An Outline of Interpretive Sociology. Berkeley, CA: University of California Press.

Wheeler, David, and Kevin Ummel. 2008. “Calculating CARMA: Global Estimation of $\mathrm{CO}_{2}$ Emissions from the Power Sector." Working Paper Number 145. Center for Global Development, Washington, D.C.

World Bank. 2009. "2009 World Development Indicators." Washington, D.C.: The World Bank. Retrieved July 1, 2016. http://siteresources.worldbank.org/ BRAZILINPOREXTN/Resources/3817166-1228751170965/WDI_2009_fullEnglish.pdf.

York, Richard. 2012. "Asymmetric Effects of Economic Growth and Decline on $\mathrm{Co}_{2} \mathrm{Emis}$ sions." Nature Climate Change 2:762-4. https ://doi .org/10.1038/nclimate1699.

York, Richard, Eugene A. Rosa, and Thomas Dietz. 2003. "Footprints on the Earth: The Environmental Consequences of Modernity." American Sociological Review 68:279-300. https://doi.org/10.2307/1519769. 
Acknowledgements: Direct all correspondence to Don Grant, Department of Sociology, University of Colorado Boulder, Boulder CO 80309. This research was supported with a collaborative grant from the National Science Foundation (\#1357483, 1357495, 1357497). We thank Jamie Vickery and Urooj Raja for their excellent research assistance. We also thank Jason Boardman and Ryan Masters for their technical comments and assistance. Liam Downey, Giacomo Negro, David Frank, Elizabeth Boyle, Sarah Babb, Juliet Schor, and audiences at the 2016 Annual Meeting of the American Sociological Association, 2016 Future of World Society Theory Conference, Boston College's Environmental Sociology Workshop, and Emory Law School provided helpful comments on earlier drafts.

Don Grant: Department of Sociology, University of Colorado Boulder.

E-mail: Don.GrantII@colorado.edu.

Andrew K. Jorgenson: Department of Sociology and Environmental Studies, Boston College. E-mail: jorgenan@bc.edu.

Wesley Longhofer: Department of Organization and Management, Emory University.

E-mail: wesley.longhofer@emory.edu. 